MEXICO'S MONETARY POLICY FRAMEWORK UNDER A FLOATING EXCHANGE

RATE REGIME

Agustín G. Carstens y Alejandro M. Werner

Mayo de 1999

Documento de Investigación No. 9905

Dirección G eneral de Investigación Económica

BANCO DE MÉXICO 


\title{
MEXICO'S MONETARY POLICY FRAMEWORK UNDER A FLOATING EXCHANGE RATE REGIME
}

\author{
Agustín G. Carstens and Alejandro M. Werner* \\ BANCO DE MÉXICO
}

May 1999

Research Paper No. 9905

\begin{abstract}
ABST RACT
The currency and financial crises experienced by the European Monetary System in 1992, by Mexico in 1994-95 and the recent emerging market crisis of 1997-1999 have reignited the debate on the viable exchange rate regimes for small open economies and, in particular, for emerging markets. After more than four years with the floating exchange rate regime, the Mexican experience provides an interesting case of study for other emerging economies considering the possibility of moving towards a more flexible exchange rate regime. In this paper we provide an overview of the transition towards the floating exchange rate regime, the functioning of this system in Mexico, the current monetary policy framework and the behavior of the economy in recent years.
\end{abstract}

\footnotetext{
* The views expressed here are those of the authors and do not necessarily reflect those of Banco de México. We appreciate the comments and contributions of Everardo Elizondo, Moisés Schwartz and Daniel Garcés.
} 


\section{Content}

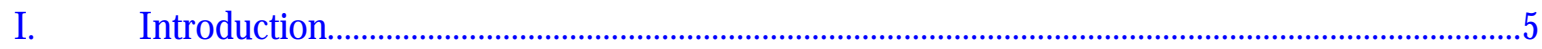

II. 1994-1995: A forced transition to the floating regime....................................................................

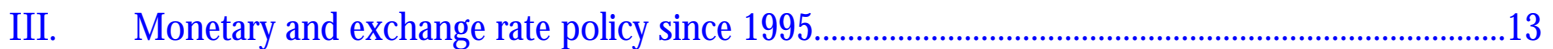

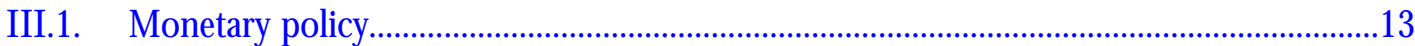

III.1.1 The identification of the Inflationary Process in Mexico .....................................21

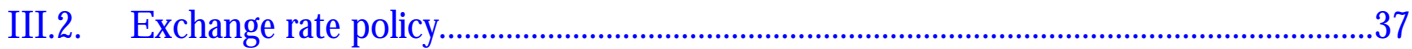

IV. Stylized Facts under Mexico's Float..........................................................................................

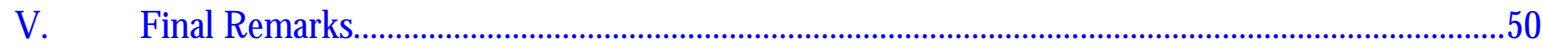

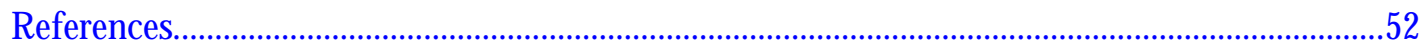

\section{List of Figures}

Figure 1: $\quad$ Interest Rate and Exchange Rate (1994-1995).....................................................................

Figure 2: $\quad$ Primary Balance (1992-1996)...........................................................................................

Figure 3: $\quad$ Current Account (1994-1996)......................................................................................

Figure 4: $\quad$ Amortization of Tesobonos (1995-1996).........................................................................12

Figure 5: $\quad$ Growth in Consumption, Investment, Exports and G DP (1992-1998)..........................13

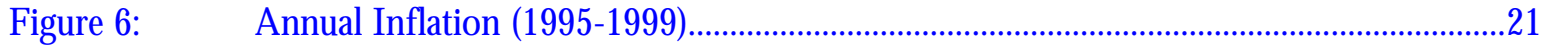

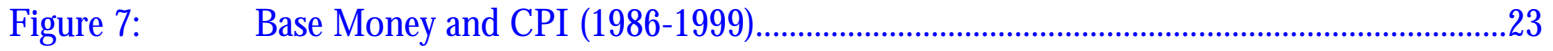

Figure 8: $\quad$ Base Money and Inflation (1987-1999)..............................................................................23

Figure 9: Impulse-Response functions.......................................................................................25

Figure 10: Inflation and exchange rate (1984-1999)..............................................................................31

Figure 11: $\quad$ Relationship between inflation expectations and the exchange rate (1997-1999)..........31

Figure 12: Tradable and non-tradable goods inflation........................................................................33

Figure 13: $\quad$ Overnight interest rate, spot exchange rate and "short" ........................................................35

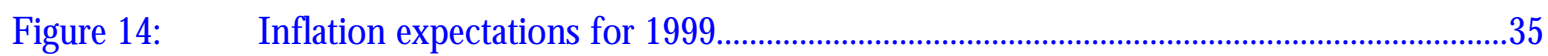

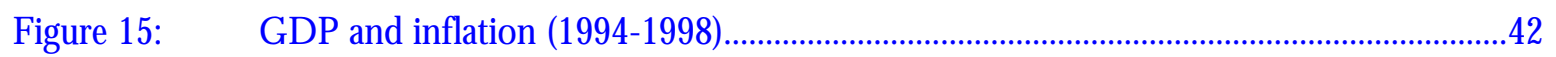


Figure 16: $\quad$ Spot exchange rate (1995-1999).................................................................................43

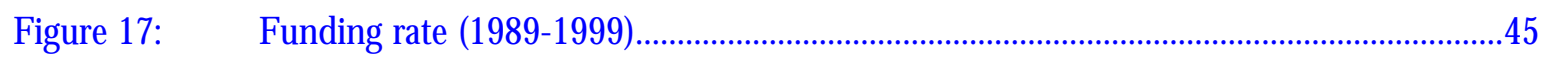

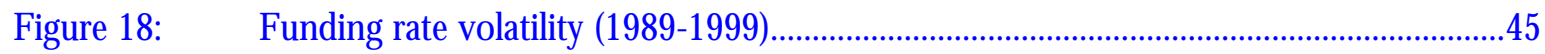

Figure 19: C Current account and foreign investment (1993-1998),.......................................................46

Figure 20: $\quad$ Average foreign direct investment for Mexico and Latin America (1991-1997)............47

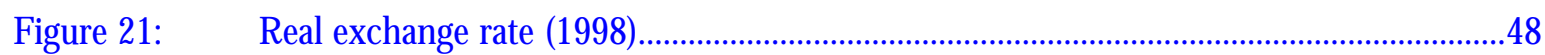

Figure 22: Nominal exchange rate (1998).......................................................................................49

\section{List of Tables}

Table 1: $\quad$ Percentage of the variance of base money explained.........................................................26

Table 2: $\quad$ Percentage of the variance of prices explained......................................................................26

Table 3: $\quad$ Percentage of the variance of wages explained.................................................................27

Table 4: $\quad$ Percentage of the variance of the exchange rate explained...............................................27

Table 5: $\quad$ Percentage of the variance of public prices explained......................................................27

Table 6: $\quad$ Estimation of the monthly inflation of non- administered prices......................................28

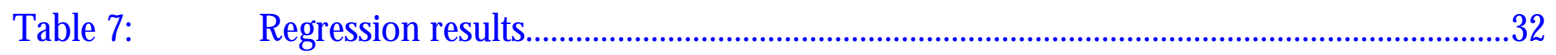

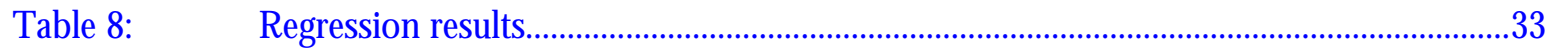

Table 9: $\quad$ Results of the auction of options......................................................................................

Table 10: $\quad$ Exchange rate volatility of some countries vis-a-vis the USD ...........................................44 


\section{MEXICO'S MONETARY POLICY FRAMEWORK UNDER A FLOATING EXCHANGE RATE REGIME}

\section{Introduction}

The currency and financial crises experienced by the European Monetary System in 1992, by Mexico in 1994-95 and the recent emerging market crisis of 1997-1999 have reignited the debate on the viable exchange rate regimes for small open economies and, in particular, for emerging markets. One common element in all of the aforementioned crises was the adherence to a predetermined exchange rate. These commitments were very costly to maintain, specially when promises not to devaluate lacked the institutional support provided by a monetary union or a currency board. In addition, as capital controls have been dismantled and financial innovation has progressed, the size and speed of capital movements has substantially increased the cost of sustaining a predetermined exchange rate.

In many cases a fixed or predetermined exchange rate regime was chosen as an instrumental element of an inflation stabilization effort. In countries where the central bank is faced with a credibility problem, a predetermined exchange rate provides a clear nominal anchor by which the central bank "borrows" the credibility of the currency to which it is pegging. Although in many of the crises countries this strategy proved successful in the fight against inflation, once inflation was brought down to manageable levels and policy priorities changed, the rigidity imposed by these regimes became a liability to the fixing countries, and when faced with significant shocks, they were forced to devalue.

Many countries under a predetermined exchange rate regime ran into the problem that at some point they assigned too many objectives to a single policy instrument. These inconsistencies eventually led to a collapse of the regime. In the case of Mexico, during 1994 monetary policy had to defend the predetermined exchange rate, without affecting a weak banking system. Recently, in the case of Brazil, interest rate policy needed to defend the currency, but without increasing the fiscal imbalance. Once the market caught the inconsistencies, the regimes were doomed.

In addition, the implicit exchange rate guarantees provided by a predetermined exchange rate, combined with a generous deposit insurance, proved to be a lethal combination that provoked excessive financial intermediation, unwise risk taking and moral hazard. These factors, in the context of a recently liberalized financial system, have generated important vulnerabilities in the financial sector, that in most cases, led to severe financial crises. A currency board arrangement, by clearly limiting the functions of lender of last resort of the monetary authorities and by minimizing (at least ex-ante) the 
deposit insurance coverage, provides a mechanism to discipline the financial sector, avoiding the generation of significant financial imbalances. On the other hand, a floating exchange rate eliminates the exchange rate insurance, limiting the extent of foreign exchange exposure by the financial institutions. Under this scheme, deposit insurance also can be limited, as México gradually has been doing.

Thus, several economists and analysts have concluded that only under very specific and demanding conditions ${ }^{1}$, there might be a comfortable middle ground between a floating exchange rate and the adoption of a common currency. Although strict capital controls could provide the needed additional instrument to sustain a less extreme regime, in practice controls have been abused and the distortions generated by them have overwhelmed their potential benefits.

In Latin America this polarization in the election of exchange rate regimes is clearly represented by the different paths adopted by Argentina and Mexico. While Argentina, in April 1991, implemented a currency board in the midst of a severe financial and inflationary crisis, in Mexico, the 1994-95 currency crisis made the adoption of a floating exchange rate the only viable option. Although at that time there was a widespread view that this was not a suitable long term regime for our country, today, after more than four years, there is a much broader consensus about the benefits and appropriateness of it.

It has been claimed [Hausmann et al (1999)] that since the 1970's Latin-American economies have been abandoning fixed exchange rates by adopting more flexible exchange rate arrangements. But, until very recently, this move implied the implementation of crawling exchange rates with or without bands. Thus, in these new regimes, the authorities still undertook important commitments regarding the behavior of the exchange rate. It is not until the late 1990's, when some Latin-American countries started abandoning exchange rate commitments and turning towards floating exchange rates.

Therefore, the recent Mexican experience with a floating exchange rate is one of the few cases of a Latin-American country that has sticked to such a regime for a relatively long period of time - not only as the only feasible alternative after a crises, but as desired exchange rate arrangement - .

After more than four years with the floating exchange rate regime, the Mexican experience provides an interesting case of study for other emerging economies considering the possibility of moving towards a more flexible exchange rate regime. In this paper we provide an overview of the transition towards the floating exchange rate regime, the functioning of this system in Mexico, the current monetary policy framework and the behavior of the economy in recent years. In the next

1 Cases that come to mind are the ones of Chile and Israel. 
section, we briefly document the transition to the floating exchange rate regime during 1994-95; in section 3 we describe how monetary and exchange rate policy are conducted under this regime; in section 4 we look at the behavior of financial and real variables during the float; and, in section 5, we conclude with some lessons from the Mexican experience and challenges for the future.

\section{1994-1995: A forced transition to the floating regime}

The fragilities accumulated during the early 1990's --the years of large capital inflows and financial liberalization--, plus the negative external and domestic shocks faced by the economy during 1994, gave way to the balance of payments and financial crisis of D ecember 1994, when under severe pressure in the foreign exchange rate market, the central bank was no longer able to defend the predetermined parity and it was decided to let the peso float. ${ }^{2}$

As the weeks went by, it became clear that the crisis had three conceptually different aspects. The first one was due to the overspending in the economy that generated a current account deficit of significant proportions. This deficit was being financed by short run capital inflows. The second aspect was the equivalent of a run on Mexican external liabilities, both government and private. While debt and budget indicators highlighted the solvency of the Mexican government, the short maturity of the stock of government debt exposed the country to a financial panic. Even when investors recognized Mexico's solvency, they realized that if everybody else stopped the roll-over of Mexican debt the country would be unable to fulfill its financial obligations. Thus, the illiquidity of the Mexican government generated a run on its debt. The third aspect was the banking crisis that began to unfold, which required immediate attention, both to avoid a domestic run on the banks and to pursue consistency in the macro framework.

2 An attempt to implement a controlled movement in the currency band was unsuccessful and lasted only one day. 
As the understanding of the nature of the crisis became clear, the policy reaction evolved from a package designed to adjust the overspending in the economy, to one that, in addition to taking these issues into consideration, generated enough confidence to stop the panic and restore confidence in Mexican assets, both external and internal. To achieve this, Mexico had to demonstrate its commitment to completely fulfill all its financial obligations without relying on inflationary finance or an outright default on debt, and at the same time applying a consistent set of policies.

Thus, in the aftermath of the 1994 devaluation of the peso, economic policy faced three immediate challenges:

(i) To conduct an orderly macroeconomic adjustment in response to the steep reduction of capital inflows.

(ii) To refinance short-term dollar denominated public debt by approximately US $\$ 30$ billion.

(iii) To maintain the solvency of the banking sector and protect depositors' savings.

In order to face these challenges, several measures were implemented during 1995:

(a) To contain the inflationary effects of the devaluation, a tight monetary policy was followed. To make this policy credible, it became essential to spell out very clearly that monetary policy was going to be oriented exclusively to stabilize the nominal variables of the economy, consistent with Banco de Mexico's autonomy. The banking sector problems were going to be dealt with specific programs (to be explained later), whose costs were going to be absorbed through fiscal adjustments spread over many years. So, monetary policy had only one objective - to reduce inflation - , a condition which was essential under a floating exchange rate regime, since under such an arrangement the said policy should be the nominal anchor of the economy. To build that anchor, monetary policy needed to be conducted without any interference from the banking sector problem. To demonstrate the resolve of the monetary authorities, it can be said that they contributed for the overnight interest rates to move from 16\% in December 1994 to 86\% in March 1995. 
Figure 1

Interest Rate and Exchange Rate

(1994-1995)

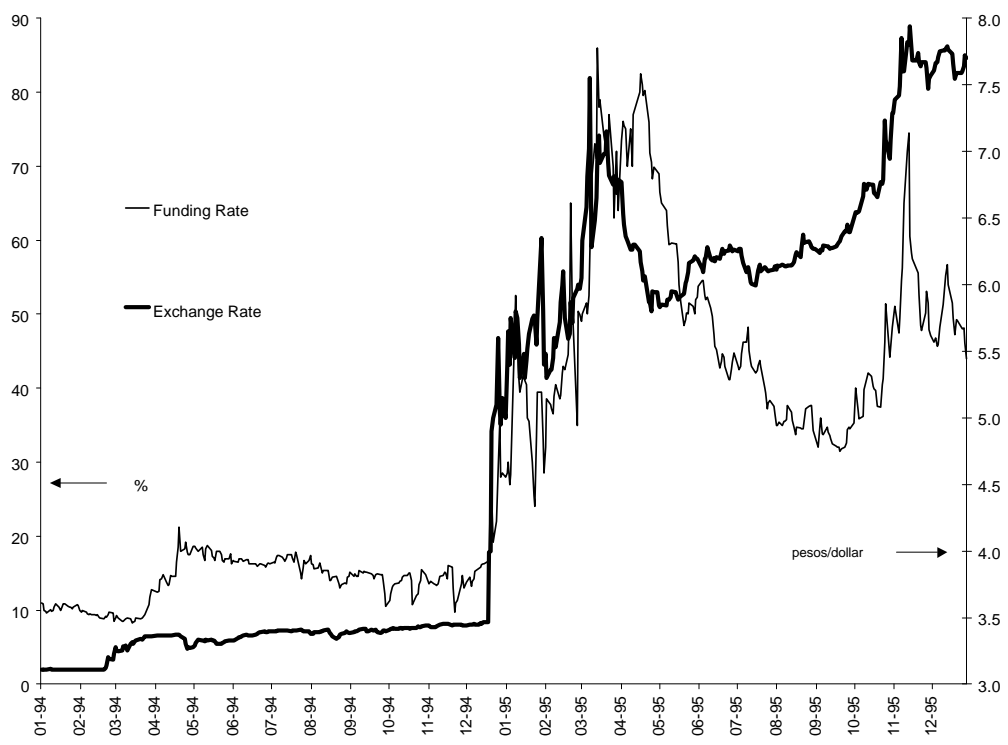

(b) In order to accomplish an orderly adjustment of the current account, fiscal policy was tightened considerably as the primary balance went from a surplus of 2.1\% of GDP in 1994 to a surplus of $4.7 \%$ of GDP in 1995, even when GDP contracted by more than $6 \%$. In addition, a fiscal effort was necessary, to start absorbing some of the costs of the banking sector rescue package. 


\section{Figure 2}

Primary Balance (1992-1996)

(as GDP percentage)

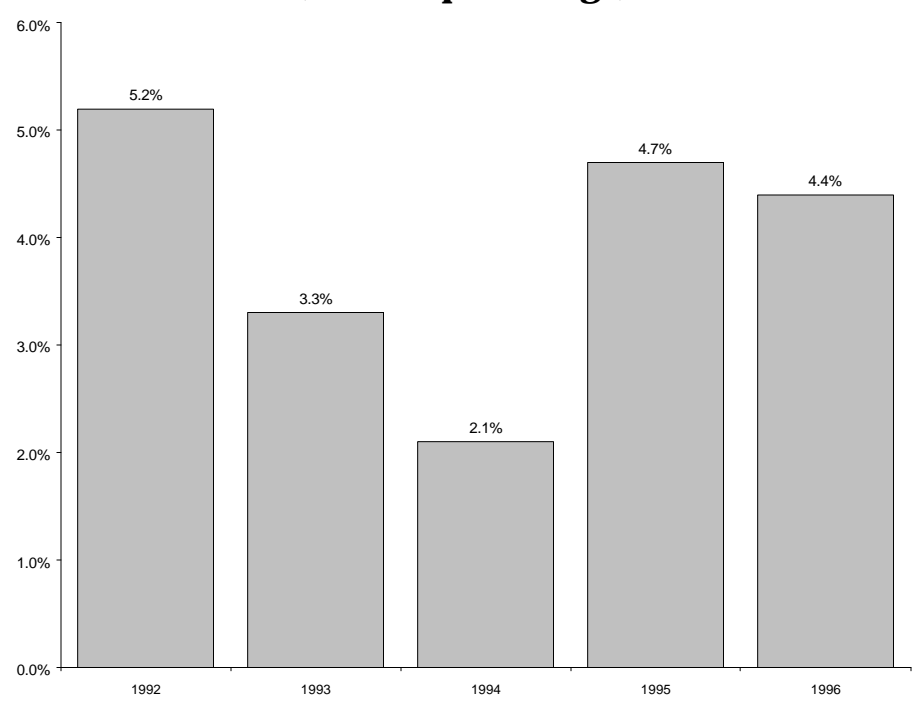

The tight monetary and fiscal policies, together with the expenditure switching effects of the devaluation, were absolutely essential to stabilize the currency and achieve the current account correction in a relatively orderly way.

Figure 3

\section{Current Account (1994-1996) \\ (millions of dollars)}

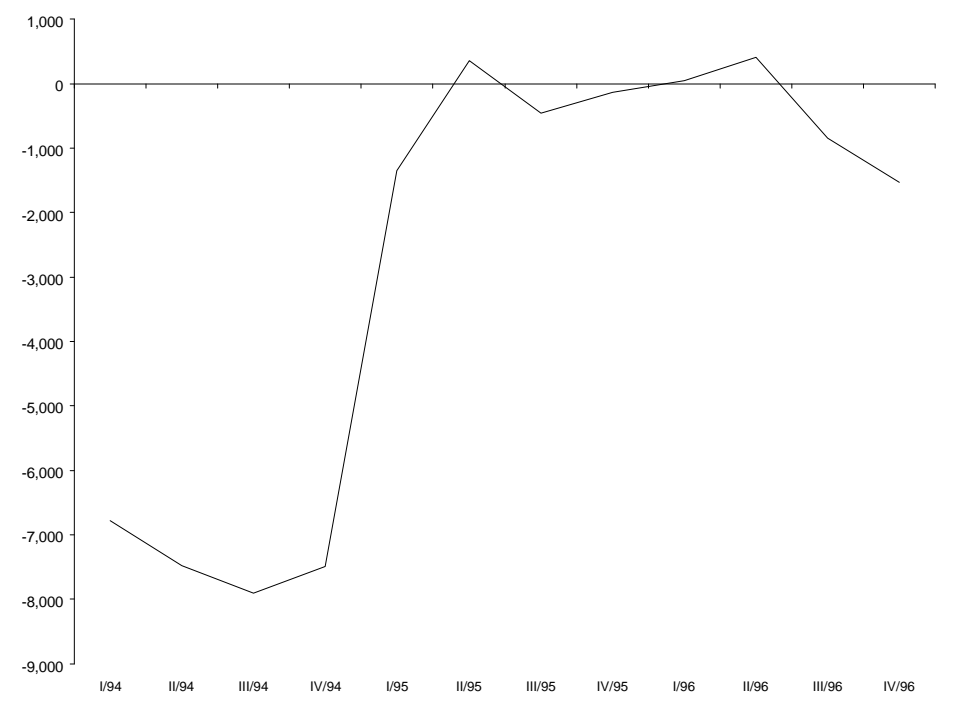

(c) To honor the financial commitments of the country, and more importantly, to induce creditors to roll-over their maturing loans to Mexico, the government negotiated and obtained a 52billion dollars emergency support package from the international community, having the US 
government [i.e. the Exchange Stabilization Fund] and the IMF as the main suppliers of assistance.

(d) To deal with the banking sector problem, a comprehensive strategy was put in place. The fragilities accumulated by the domestic financial system, the overindebtness of firms and households, and the damaging effects of the crisis seriously threatened the health of the Mexican financial system. To preserve the integrity of this sector, the authorities implemented a series of programs, with the following objectives:

- To prevent a systemic run on the banking system;

- To combat moral hazard and minimize distortions;

- To consider the cost of the banking sector restructuring as a fiscal issue;

- To reduce as much as possible the need for the central bank to act as the lender of last resort; and

- To strengthen financial sector regulation and supervision.

Based on these objectives, the central bank opened credit lines denominated in foreign currency at a penalty rate, so that commercial banks could fulfill their external obligations; a program was established to promote the capitalization of the banking system; and legal reforms were undertaken to allow greater foreign participation in the banking system.

It should be highlighted that the fiscal authority, by recognizing the fiscal costs of the banking sector restructuring and by showing its commitment to deal with this problem with fiscal resources, liberated monetary policy to pursue its primary goal of price stability. Thus, at this point it was clear that monetary policy would not face the dilemma of trying to comply with conflicting objectives and that it would concentrate in lowering inflation, becoming the required nominal anchor under the floating exchange rate regime.

Low international reserves and the uncertainty prevailing in financial markets after the collapse of the currency made the discussion on alternative exchange rate regimes irrelevant. The only option was to stick with a floating exchange rate. Therefore, the important issue was to implement the necessary institutional and operational innovations to complement the floating exchange rate regime and start to reestablish the credibility of Banco de México (more on this on the next section). 
Following the implementation of the strategy, financial markets recognized the soundness of the measures taken, and the commitment of the Mexican government to pay all of its maturing debt. The peso became more stable, and after overshooting to 7.5 pesos per dollar in March, it went back in May to 6 pesos per dollar, regaining some of the ground lost during the weeks of uncertainty. Interest rates began to fall and the stock market returned to its pre-crisis level. The inflation rate quickly came down to manageable levels. The risk of a government default disappeared as TESOBONOS outstanding were being paid off in dollars and the government had sufficient resources to accomplish this task. Finally, it is important to notice that the Mexican government, as well as some private banks, regained access to international capital markets soon after the announcement of the program. Because of this, the Mexican authorities used only half of the emergency support provided by the US government, and these loans were paid in full by January 1997, three years before schedule.

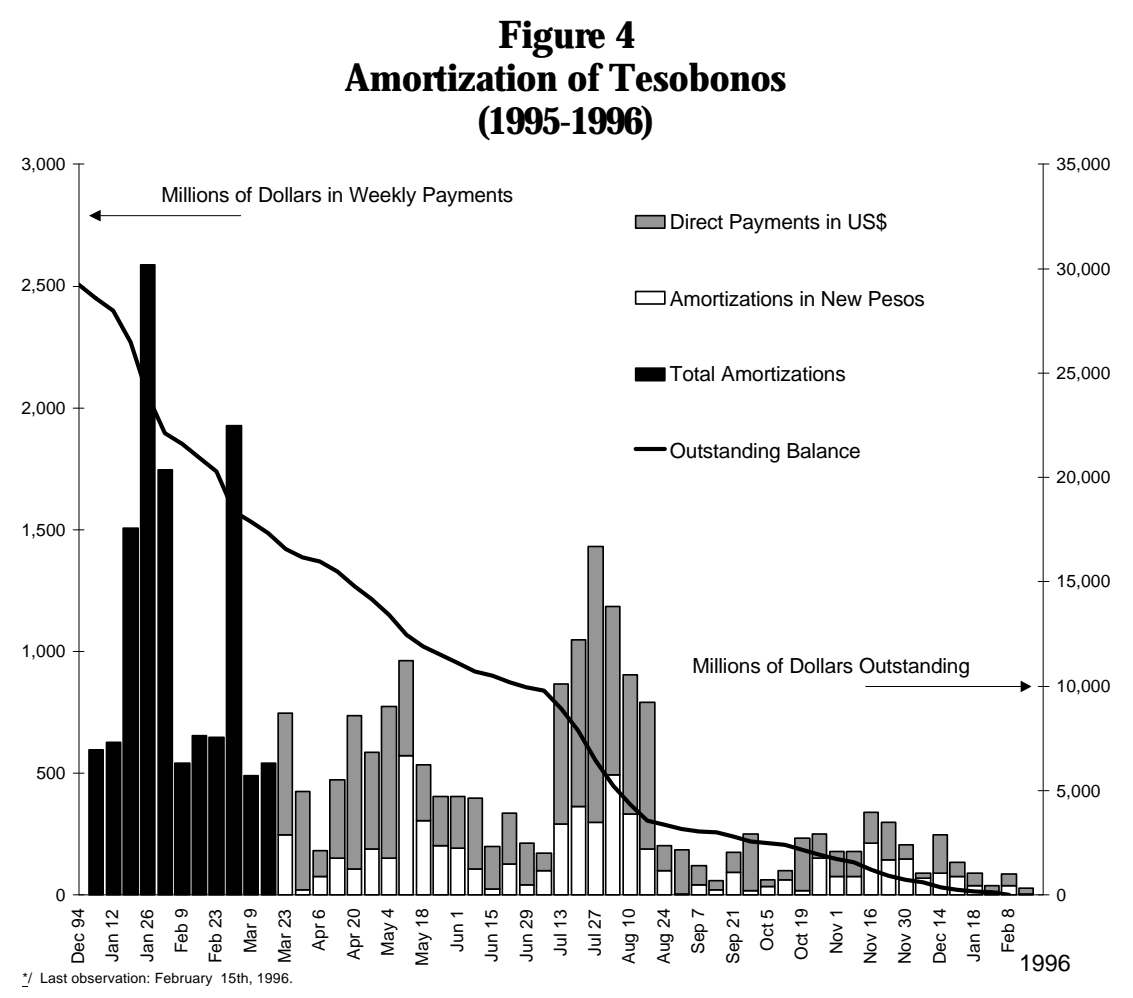

The real economy showed an impressive turnaround in the external accounts. Exports increased by 30.6\% from 1994 to 1995; and the trade deficit of \$ 18,464 billion in December of 1994 turned into a surplus of $\$ 7,088$ billion in December of 1995. Economic activity and employment suffered considerably by the fall in domestic demand, due to the capital flows reversal, the reduction in government spending, increases in tax rates, high real interest rates and vanishing credit. Specifically, output, consumption and investment fell by 6.2, 8.4 and 29 percent, respectively, during 1995. 
As the exchange rate stabilized, interest rates fell, international financial markets resumed lending to the Mexican economy, and the expenditure switching effects of the devaluation continued (for consumption as well as investment). Economic activity recovered rapidly, thanks to the broad restructuring that the economy had gone through in the previous decade. Thus, GDP grew 5.6 percent in average for the period 1996-98, while consumption and investment also recovered. At the same time, inflation dropped rapidly from $51.7 \%$ in 1995 to $18.6 \%$ in 1998.

\section{Figure 5 \\ Growth in Consumption, Investment, Exports, and GDP (1992-1998) \\ (growth rates)}

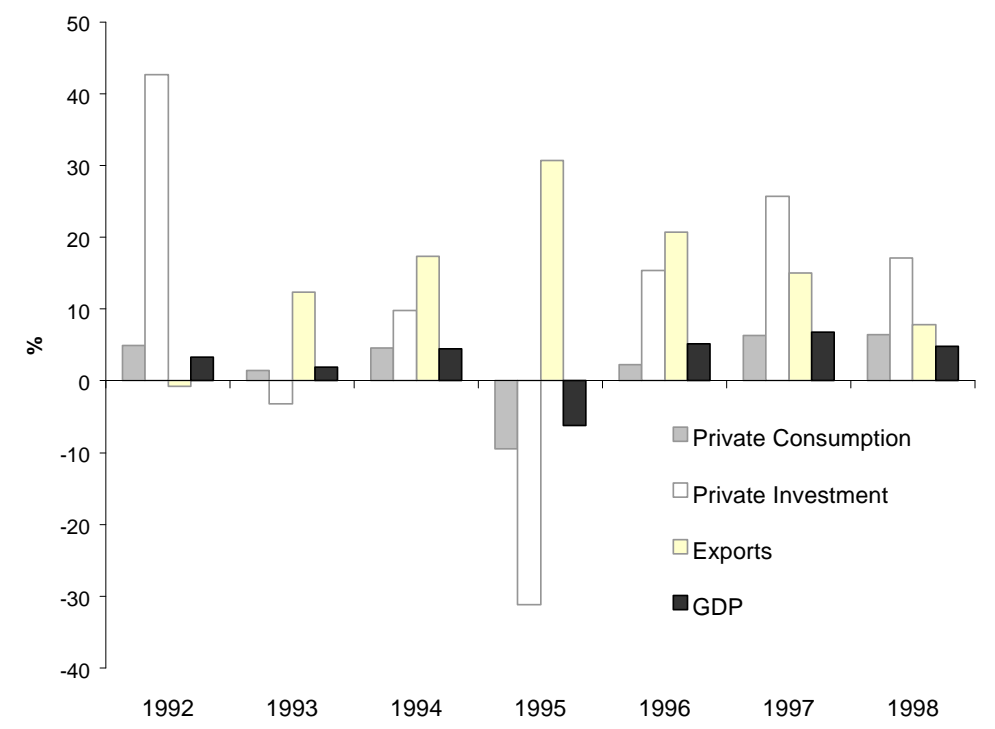

The conclusion of this section is that the key for the success of the Mexican economy in stabilizing relatively quickly its nominal variables after the eruption of the crisis in 1994-1995, was that a consistent macroeconomic program was adopted early in the last year mentioned. Therefore, even though México did not have any experience under a floating exchange rate regime, this aspect was not an impediment for pursuing stability, as long as a consistent policy framework was in place.

\section{Monetary and Exchange Rate Policy Since 1995}

\section{III.1. Monetary Policy.}

As a consequence of the devaluation of the peso and the return to a high inflation environment in 1995, the credibility of Banco de México was seriously damaged. The criticisms (some of them unfounded) concentrated mainly on two issues: (i) the lack of transparency in the conduct of monetary policy and in the dissemination of information, and (ii) the lack of ability to tighten monetary policy before, during and immediately after the crisis. 
In addition, after dropping the exchange rate as the nominal anchor of the economy and turning to a floating exchange rate regime, monetary policy had to fill the vacuum and become the nominal anchor.

In theory, under a floating exchange rate regime the central bank acquires control over the monetary base, since it does not have to add or subtract liquidity derived from compulsory interventions in the foreign exchange market. By acting directly on the monetary base, the central bank supposedly would be able to influence interest rates and the exchange rate, and through these, the general price level. Consequently, as the central bank reduces inflation, monetary policy becomes the anchor for the evolution of the general price level. These were the type of arguments that prompted the Mexican authorities to consider quantitative targets on monetary aggregates in early 1995 when designing its monetary program for the year.

Consistent with the above, Banco de México established as intermediate target a ceiling on the growth of the monetary base for the year. Since this program was just announced at the inception of the crisis, an assumption of no international reserves accumulation was made -- which is a natural assumption under a flexible exchange rate regime. Therefore, the ceiling on monetary base growth was in essence a ceiling on the expansion on the net domestic credit of the central bank, which in principle would keep inflation in line. For this quantitative target to become credible, Banco de México committed to inform monthly on the evolution of its net domestic credit.

Regretfully, very soon it became obvious that this very simple and intuitive monetary program was not enough to stabilize inflationary expectations, the exchange and the development of inflation itself. In early 1995, the rule-based monetary policy failed to perform as expected, due to the following:

(a) In a crisis scenario, the velocity of money is very unstable, thus making also unstable the relationship between the monetary base and inflation;

(b) It was not possible for the rule on monetary base growth to prevent the sudden exchange rate depreciations --resulting from external shocks or shifts in expectations--, to substantially affect inflationary expectations and eventually the price level; since the beginning, just after the collapse of the predetermined exchange rate regime, the pass-through from exchange rate depreciation to inflation was very high; and

(c) The central bank had hardly any control on the monetary base in the short run. The evolution of this aggregate is driven by the demand for bills and coins in circulation, which has a very low interest rate elasticity in the short term. In addition, commercial banks did not hold any excess reserves in the central bank --due to the zero reserve requirement policy in place and the 
operation of México's payment system--, which prevented even more any short term control over the monetary base.

In February and March, 1995, the market participants expected a strong statement by the authorities, that would make credible their stated intentions about reducing inflation. In particular, they were expecting considerable hikes in interest rates, to counteract the inflationary shocks that were occurring. So, in late March, the central bank increased up to 100 percent the overnight funding rate (by establishing interest rate floors in its open market operations). This discretionary monetary policy action, together with the agreement with the IMF of a strong adjustment program and the availability of the Exchange Stabilization Fund, managed to brake the sharp tendency towards depreciation that the peso showed during the first quarter of the year, to stabilize inflationary expectations and, very soon afterwards, to reduce the monthly rates of inflation. By May, 1995 the peso started to appreciate and inflationary expectations to fall, which led to a reduction in nominal and real interest rates. This, in turn, mitigated the collapse of economic activity and prevented further deterioration in the banking system.

Therefore, the experience just described led the Mexican authorities to modify during the first half of 1995 its monetary policy: from one based solely on quantitative targets on monetary aggregates, to another were both rules (on the behavior of the monetary base) and discretion (by influencing the level of interest rates) were incorporated.

To be able to implement in a transparent fashion the discretionary policy measures, and also to tackle the criticisms that Banco de México was too slow and undecisive to adjust interest rates, the central bank decided to adopt a new reserve requirement scheme, the so called zero average reserve requirement.

By means of this scheme3 ${ }^{3}$ Banco de México established accounting periods of 28 days during which banks seek to post a zero daily average balance in the current accounts they hold in the central bank. Banks strive to obtain said balance because, should the daily average balance be negative, the bank in question would have to pay an interest rate equivalent to twice the prevailing 28-day CETES rate on the respective balance. On the other hand, should the daily average balance be positive, the bank would lose the returns it could have obtained had it invested in the market the respective funds.

In order to meet the demand for bills and coins, the Banco de México offers credit to banks via daily auctions, so as to offset maturing credits previously granted to banks, movements in the Federal Treasury's account, and the monetary impact of transactions of foreign currency by the central bank.

3 For a detailed description of this mechanism, see Gil Díaz, Francisco (1998). 
The central bank determines the sum of credit to be auctioned each day so that the overall net daily average balance of all current accounts held by banks at the Banco de México - accumulated during the specific accounting period-may close the day at a predetermined amount. If said amount is negative, the central bank would put the banking system in "short" and, if the amount is positive, the system would be put in a long position. It follows that if the central bank puts the system in "short" (or applies a "short"), at least one credit institution will have to pay the penalty interest rate of twice the prevailing CETES rate.

It should be stressed that the Banco de México always supplies the credit necessary to completely satisfy the demand for bills and coins, even when the banking system is put in "short". Nevertheless, in this case, a portion of the credit is supplied at a higher interest rate, which is applied to the overdrafts in the current accounts of one or several banks.

When the system is put in "short", the central bank exerts upward pressure on interest rates, which can be quite significant. Nonetheless, more than for any other reason, said pressure is the result of the signal given by Banco de México. A point in case is that the maximum amount for which the system has been short in recent years is 160 million pesos, representing only $0.002 \%$ of the monetary base.

The main reason for the "short" to be effective in inducing hikes in interest rates, is because under a floating exchange rate regime the commercial banks do not have means to create balances in their accounts with the central bank (they cannot credit their balances by selling forex to the central bank, as they can do under a predetermined exchange rate regime). Therefore, the "short" imposes an unavoidable cost to the banking system. Under such circumstances, the rational response of the banking system is to allow interest rates to increase to the level they believe is the target of Banco de México, with the smallest possible "short" (or "corto" in Spanish). This is precisely what usually happens when a "corto" is applied or modified.

During 1995, Banco de México adopted additional measures geared towards strengthening those previously mentioned and to ensure better monetary control. Among these, the following should be noted:

1) Modifications to the auction mechanism that the central bank uses in order to regulate liquidity (i.e. the mechanism it depends on to conduct open market operations). Before, Banco de México frequently fixed interest rates when operating in the money market or directly influenced them by signaling maximum or minimum levels in auctions. Currently, rates are totally and freely determined in auctions. 
2) The payments system reform. Due to this amendment, daily (and intra-daily) access to the central bank credit by commercial banks has been severely constrained. Also, such credit is conditional upon the constitution of guarantees.

3) Banco de México imposed an aggresive policy on disclosure of information. For economic agents to properly follow central bank decisions, it is convenient to have access to relevant information on a timely basis. Consequently, Banco de México has been: (a) publishing, on a daily basis, the balances of the current accounts that banks hold in the central bank reported at the opening of each day, as well as the stock of bills and coins in circulation and the programmed open market operations to be conducted for that day; (b) releasing, weekly and monthly, the figures of the main items of the Bank's balance sheet, including the monetary base, net domestic credit and international reserves; and (c) making the ample data base of the Bank available to the general public through the INTERNET system. This policy has allowed a substantial reduction in the lag between the dates in which figures are known and those in which they are usually disclosed by means of printed media. These practices have situated Banco de México at the forefront of central banks regarding public information disclosure and its timeliness.

Since 1996, all the monetary programs that Banco de México has implemented are fundamentally based on the elements just outlined. To be more precise, it can be said that México's most recent monetary programs have included three main elements:

(1) A yearly annual inflation objective. This objective is established jointly by the Federal Government and the Banco de México, and it is perceived as the result of a concerted effort to coordinate fiscal and monetary policies. Based on such objective the fiscal and monetary policies are designed, and it also helps for the determination of the minimum wage.

(2) Rules defined on the behavior of monetary base, together with quantitative commitments on the accumulation on net international reserves and the variation of net domestic credit. The basic objective of these rules and quantitative commitments is to assure the market that Banco de México will not create the most basic source of inflation: excess supply of primary money. This, if it were to occur, would immediately raise the public's inflationary expectations, which would, in turn, result in exchange rate depreciation, interest rate increases, higher nominal wages and rises in the prices of goods and services. This is why the Board of Governors has 
established, as one of the elements of its monetary programs, a basic operational rule that assures that the central bank will not create a monetary base surplus. This rule goes as follows:

\section{As a general rule, Banco de México will adjust, on a daily basis, the supply of primary money in a way that such supply matches the demand for base money.}

This basic operational rule means, in more technical terms, that in the daily determination of its open market operations, the central bank will pursue, as a general rule, the objective of zero accumulated current account balances that commercial banks hold with this central bank. It also implies that Banco de México will sterilize the monetary impact that can derive from variations in the net international assets, and from operations that the Treasury carries out in the account it holds with Banco de México.

The strict application of this basic operational rule, under certain circumstances, could imply that Banco de México passively accommodates any demand of monetary base, which could be the source of some problems. In particular, the central bank could eventually be satisfying a demand for money consistent with a higher than expected inflation pattern.

To detect this situation and act in consequence, Banco de México compares daily the observed path of the base with one that is, in principle, consistent with the inflation objective for that year (which is published). This last path is difficult to determine in such a way that it has annual validity, due to the following factors: (a) the relationship between inflation and base money can change over time; (b) the basic assumptions made to forecast base demand for the year (related to the GDP growth and interest rate behavior) may not materialize, and (c) the relationship between base demand and the variables that explain its behavior might also change over time. For this reason, Banco de México must evaluate the divergences between the observed and estimated base path along with other indicators that could give more information about the evolution of future inflation, such as the exchange rate, the available measures of inflationary expectations, contractual wages and the relationship between potential and observed GDP. Given this caveats, the announced path of the monetary base does not constitute a formal policy objective. 
The usefulness of the announced path lies mainly on the fact that it would be a signal of alert in case there were important deviations between the observed and the announced base paths. Banco de México evaluates such deviations and only in case they respond to circumstances implying additional inflationary pressures, Banco de México would be expected to adopt a restrictive position.

Banco de México is capable of adjusting primary money supply to its demand by means of variations either in its domestic credit or its net international assets. The central bank has relatively more control over its domestic credit. This is why using it wrongly is, potentially, the easiest way to generate an excess in the monetary base. In response to these considerations, and with the purpose of giving additional assurance that no inflationary pressures will surge, Banco de México has decided to incorporate in its monetary programs quarterly limits to the domestic credit variations. The rest of the expected increase in the demand for base money should then be generated by increases in net international assets.

The monetary authorities have estimated that the availability of a greater amount of international assets, will contribute to further strengthen Mexico's external financial position, what is particularly important in the present highly volatile environment registered in the international financial markets. More solidity in that front will allow the country to continue having access to foreign resources, under favorable conditions with regard to the cost and maturity of foreign financing. This is why usually an important part of Banco de México's monetary programs consists of the commitment to generate a minimum net international asset accumulation. possibility for the central bank to adjust its stance on monetary policy, in case unexpected circumstances make it advisable. This element portrays the use of discretion in monetary policy management.

The element of the monetary programs described under item (2) above is aimed at preventing Banco de México from creating any excess supply in monetary base. Unfortunately, this is not a full guarantee for attaining the desired abatement of inflation. As it has been hinted before in this document, this is due to the fact that inflation may also surge from other sources. On one hand, external disruptions may cause an excessive depreciation of the domestic currency. On the other, contractual wage negotiations might result above the sum of the inflationary target plus 
productivity increases. By the same token, there could be unexpected adjustments to public prices with the purpose of keeping public finances under control.

Any of these events could cause interest rates to rise, tending to mitigate undesirable inflationary pressures. Nevertheless, the case may be that interest rates' automatic adjustment does not suffice to assure inflation's reasonable behavior. Under such circumstances, Banco de México would consider the possibility of restricting its monetary policy by means of the "short".

By increasing its "short", the central bank raises its negative target for accumulated balances of the current accounts commercial banks maintain in Banco de México. Through this action the central bank exerts an upward influence on interest rates which, in general, results from the signal sent to the market through this instrument, as it was explained before.

The above paragraphs may be summarized as follows: Banco de México, under the current circumstances of financial market volatility, requires the faculty of being able to discretionarily adjust monetary policy, particularly restricting it if necessary.

The central bank tends to use the "short", thereby adopting a more restrictive stance on monetary policy, under the following circumstances:

(a) In case it detects future inflationary pressures inconsistent with the attainment of the inflationary target. Namely, monetary policy will strive to neutralize exogenous shocks's side-effects on prices and will occasionally act in a precautionary fashion by partially compensating the direct inflationary effects of the key prices in the economy. The ultimate objective resides in making the necessary adjustments in order for relative prices to impact the CPI only moderately -by raising its level- without deteriorating inflationary expectations in order to prevent inflation's dynamics from turning perverse;

(b) When it is deemed necessary to restore order in exchange and money markets; and,

(c) When inflationary expectations are deemed out of line with respect to the original target.

The combined use of rules and discretion in monetary policy has worked well for the case of México. So far, inflation has been reduced from 52 percent in 1995 to 18.6 percent in December, 1998 
and 18.2 percent in last March. For 1999 as a whole inflation is expected to fall to 13 percent (see figure 6).

Figure 6

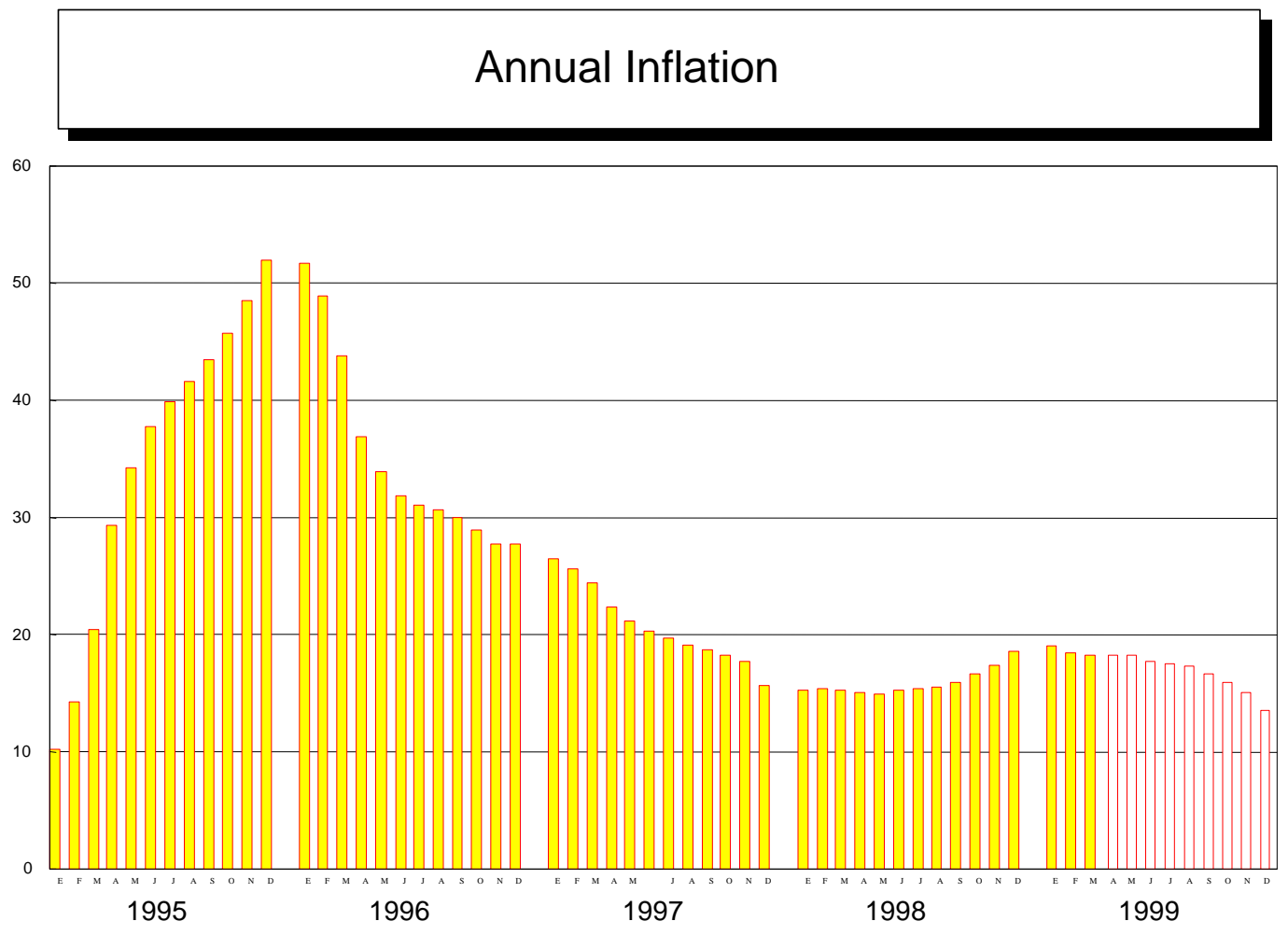

As a matter of fact, as the understanding of the inflation phenomena in México is increased, the more evident it becomes that the real nominal anchor of the economy is the discrete response of authorities to shocks. This sends a clear signal to the market about the authorities' commitment to attain the inflation objectives.

As these are achieved, the more credible the policy and the objectives will be. Therefore, it could be said that México is in the transition period towards a clear-cut inflation targeting scheme. As it will be apparent from the next subsection, the main factor that has prevented México from adopting an explicit inflation targeting scheme is the frequency and incidence of exogenous shocks - both domestic and external- to the price level.

\section{III.1.1 The Identification of the Inflationary Process in México.}

To design a suitable monetary policy framework, it is essential to understand which are the main determinants of inflation, and how does monetary policy interact with them to affect the behavior of the rate of increase of the CPI. 
As we all know, inflation is ultimately a monetary phenomenon. The evidence is clear that in the medium and long run, there is a very close correlation between the rate of growth of monetary aggregates and inflation, once changes in output and velocity are taken into account. This correlation has been observed both in the international (see Lucas (1996)) and Mexican experiences (figures 7 and 8). 


\section{Figure 7}

Base Money and CPI

(1986-1999)

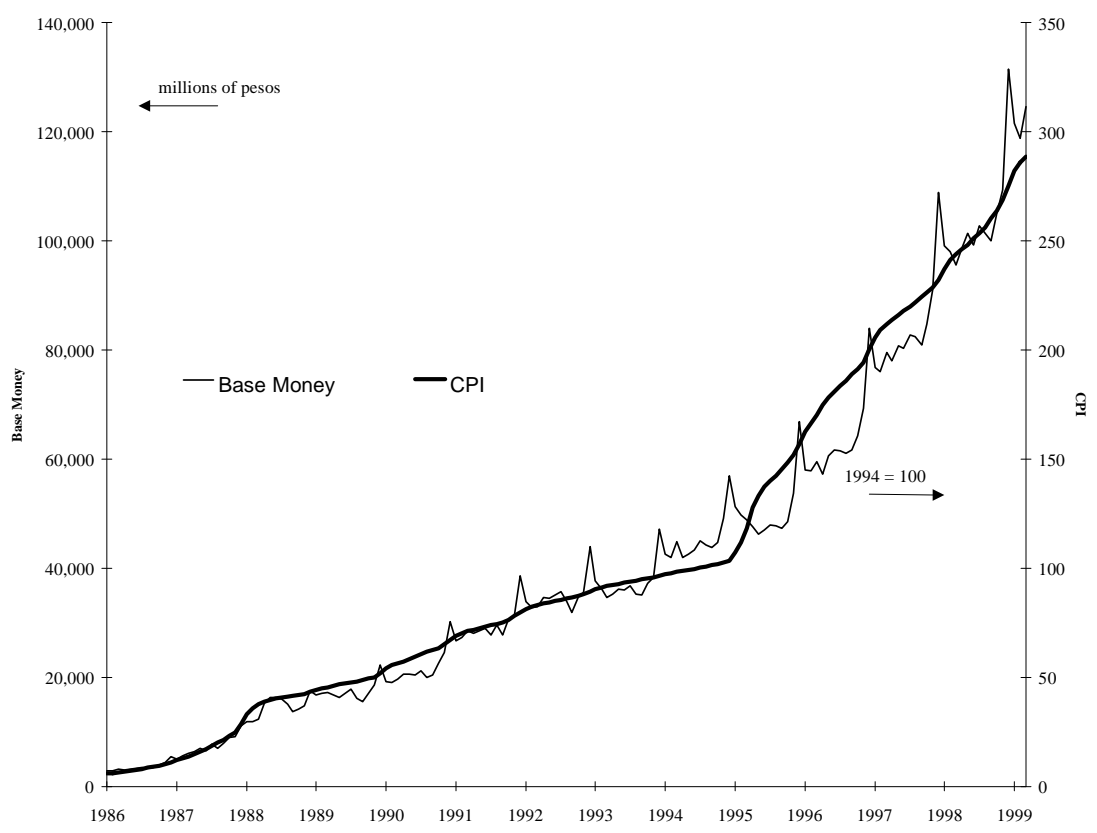

Figure 8

Base Money Growth and Inflation

(1987-1999)

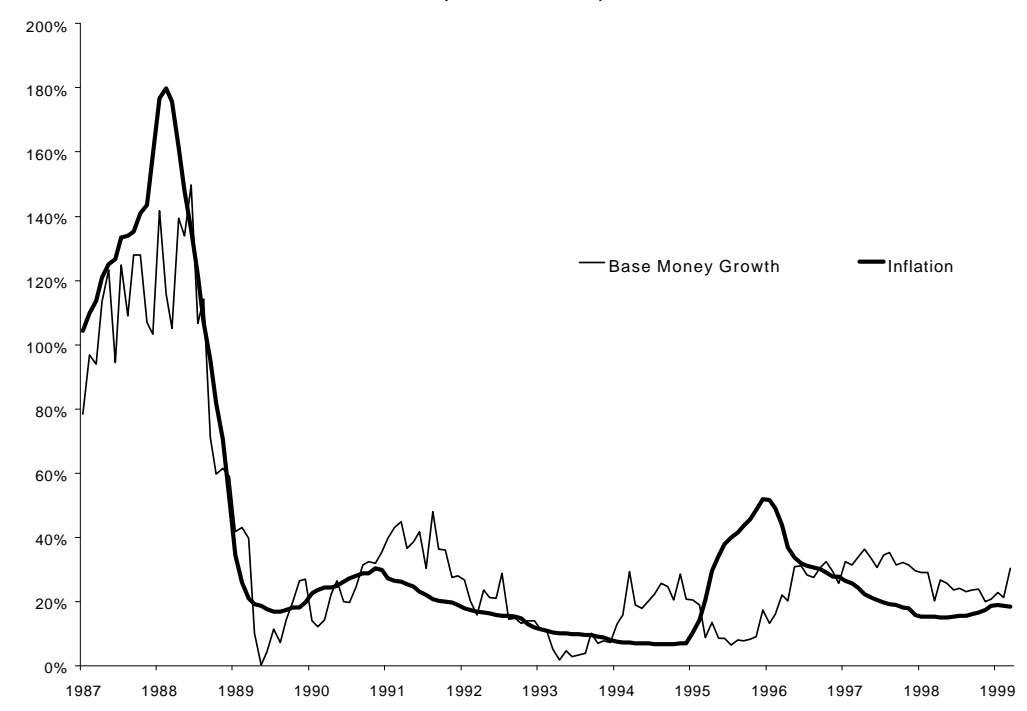

A quick reading of these findings might suggest that it should be relatively simple for the central bank to eradicate inflation, given its influence on the behavior of monetary aggregates and high power money in particular. But as we all know, the close correlation between money and prices says nothing about causality running in either direction. 
Economic theory is useful to frame this discussion on causality. On the one hand traditional monetary models with flexible prices imply that causality goes from money to prices. In this setup, prices will adjust immediately to changes in the stance of monetary policy. For instance, if the monetary authority decides to reduce the rate of growth of the monetary base, agents will adjust their expectations accordingly and inflation will immediately converge to its long run equilibrium. On the other hand, models with price rigidities imply that in the short run inflationary shocks, such as wage increases that are inconsistent with the inflation target, cannot be offset immediately by the monetary authority. The monetary authority could in principle maintain the money supply constant, however, given the low elasticity of the demand for real balances, the decrease in real balances would send interest rates through the roof. Under this circumstances, the central bank will be obliged to accommodate, totally or partially, the inflationary impact of such shock. In this case, the causality is turned on its head running from prices to money. Therefore, in this scenario, to judge the stance of monetary policy, we should focus on the degree of accommodation by the monetary authority. But even if the monetary authority accommodates the inflationary shock only partially, real interest rates will increase. This increase in real interest rates will slowly reverse the impact of the inflationary shock by affecting aggregate demand and appreciating the currency.

This discussion highlights two alternative sources of inflationary pressures. First, we have the traditional monetary explanation, where exogenous shocks to the supply of money cause inflation, therefore money is the driving force of the inflationary process. Secondly, in models with price rigidities, shocks to key prices in the economy (wages, exchange rates and public sector prices) directly affect inflation, and monetary policy partially accommodates these shocks. In this scenario, the degree of policy accommodation will be instrumental in determining the long-run inflationary impact of the shocks.

A first step in designing a suitable monetary policy framework is to determine wether the inflationary process in Mexico is driven mainly by exogenous monetary shocks or by shocks to key prices that are partially accommodated by the monetary authority.

Taking a close look at the evolution of the growth rate of the monetary base and inflation during the period 1986-1998 (see figure 8), it seems that changes in inflation have preceded changes in the growth rate of base money. Therefore, it seems that during this period, exogenous movements in money were not the fundamental cause of inflation. To analyze this result more formally, Granger causality tests were performed. The results of these tests show that there is causality running both ways between these two variables. However, these results do not quantify the influence that movements on each of these variables had on the other. To analyze this issue in more detail, we estimated a Vector Error Correction Model (VECM) that incorporates, as its endogenous variables: CPI, base money, 
exchange rate, wages and public sector prices. The impulse response functions are presented in figure 9 and the results from the variance decomposition 4 are shown in tables 1 to 5.

\section{Figure 9}

\section{Impulse-Response functions}

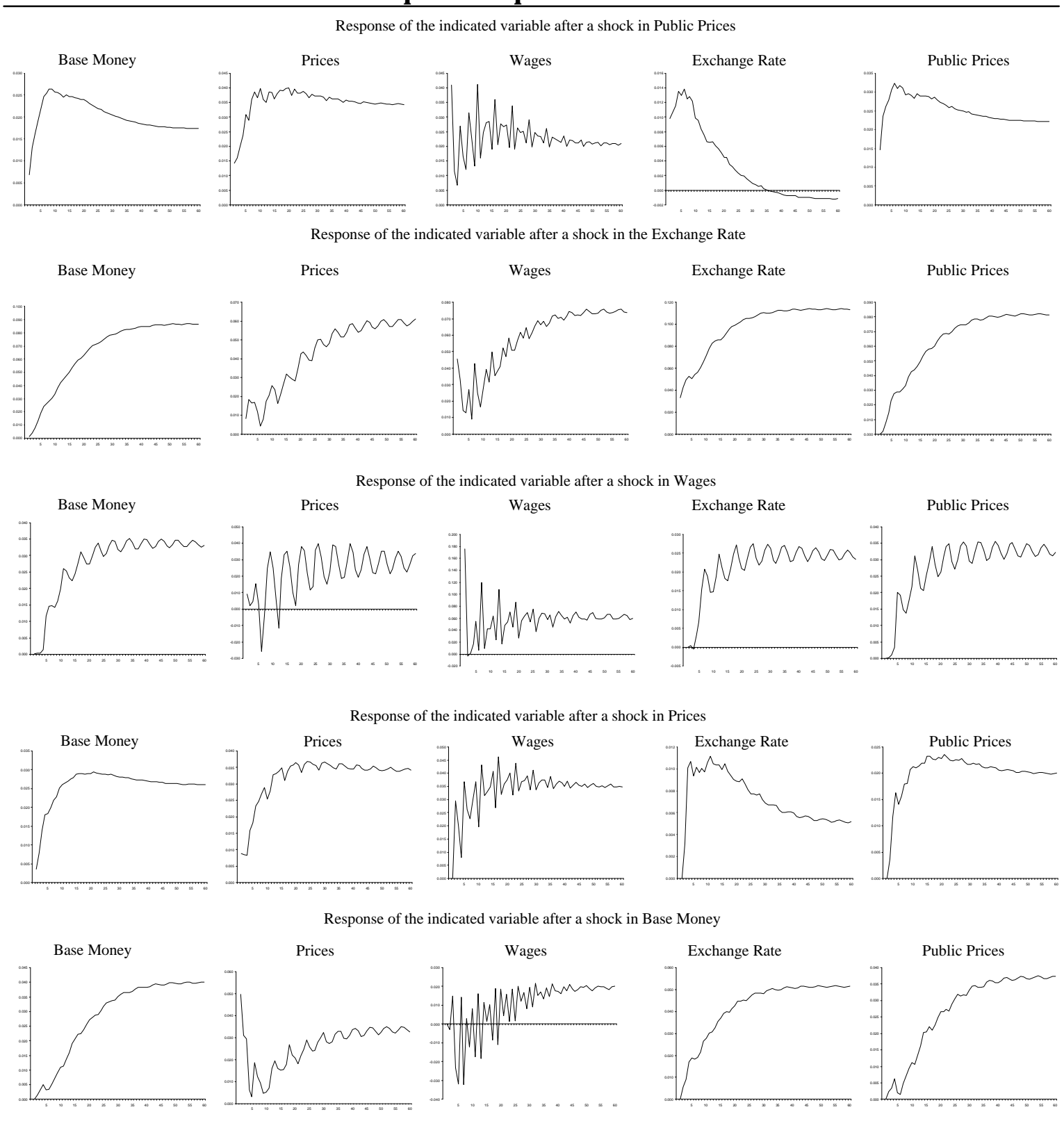

From the impulse response functions it seems that the shocks have been correctly identified. Public prices, exchange rate and wage shocks have positively affected the price level and money. It is

4 The ordering of the variables for the identification of the shocks was: public sector prices, exchange rate, wages, prices and monetary base. However, the results are robust to changes in the ordering of the variables. 
also evident that each of these shocks has had indirect effects on the other two key prices of the economy. Finally, it is interesting to notice that money shocks have the expected effect, as they bring about increases in all prices in the economy. To establish the relevance of each shock as a determinant of the movements in the other variables in the system, the variance decomposition for each variable can be of assistance.

Table 1

Percentage of the Variance of Base Money Explained by

\begin{tabular}{crrrrr}
\hline months & Public Prices & Exchange Rate & Wages & Prices & Base Money \\
\hline $\mathbf{6}$ & 26.58 & 9.33 & 8.40 & 11.12 & 38.96 \\
$\mathbf{1 2}$ & 37.43 & 11.11 & 11.89 & 19.62 & 17.30 \\
$\mathbf{1 8}$ & 35.71 & 14.32 & 12.46 & 22.64 & 13.13 \\
$\mathbf{2 4}$ & 32.36 & 19.74 & 12.44 & 22.62 & 11.72 \\
$\mathbf{3 0}$ & 29.02 & 24.38 & 12.49 & 21.68 & 11.63 \\
\hline
\end{tabular}

Table 2

Percentage of the Variance of Prices

Explained by

\begin{tabular}{crrrrr}
\hline months & Public Prices & Exchange Rate & \multicolumn{1}{c}{ Wages } & \multicolumn{1}{c}{ Prices } & Base Money \\
$-\mathbf{6}$ & 39.68 & 24.43 & 7.16 & 27.38 & 1.24 \\
$\mathbf{1 2}$ & 26.49 & 35.53 & 12.27 & 22.71 & 2.95 \\
$\mathbf{1 8}$ & 17.67 & 44.83 & 12.89 & 18.40 & 6.02 \\
$\mathbf{2 4}$ & 12.85 & 50.92 & 12.58 & 15.07 & 8.05 \\
$\mathbf{3 0}$ & 9.97 & 54.75 & 12.12 & 12.80 & 9.49 \\
\hline
\end{tabular}


Table 3

Percentage of the Variance of Wages

Explained by

\begin{tabular}{crrrrr}
\hline months & Public Prices & \multicolumn{1}{c}{ Exchange Rate } & \multicolumn{1}{l}{ Wages } & \multicolumn{1}{c}{ Prices } & \multicolumn{1}{c}{ Base Money } \\
\hline $\mathbf{6}$ & 6.20 & 8.91 & 70.55 & 6.97 & 4.11 \\
$\mathbf{1 2}$ & 8.06 & 11.49 & 63.13 & 10.42 & 4.23 \\
$\mathbf{1 8}$ & 8.37 & 15.88 & 57.89 & 12.32 & 3.45 \\
$\mathbf{2 4}$ & 8.05 & 21.09 & 53.18 & 13.06 & 3.02 \\
$\mathbf{3 0}$ & 7.51 & 25.71 & 49.55 & 13.16 & 2.80 \\
\hline
\end{tabular}

Table 4

Percentage of the Variance of Exchange Rate

Explained by

\begin{tabular}{crrrrr}
\hline months & Public Prices & Exchange Rate & Wages & Prices & Base Money \\
$-\mathbf{6}$ & 5.35 & 81.79 & 1.77 & 2.51 & 6.57 \\
$\mathbf{1 2}$ & 2.97 & 78.56 & 4.55 & 1.93 & 9.66 \\
$\mathbf{1 8}$ & 1.61 & 77.71 & 4.62 & 1.43 & 11.74 \\
$\mathbf{2 4}$ & 1.00 & 77.25 & 4.48 & 1.08 & 12.81 \\
$\mathbf{3 0}$ & 0.69 & 76.89 & 4.33 & 0.85 & 13.50 \\
\hline
\end{tabular}

Table 5

Percentage of the Variance of Public Prices

Explained by

\begin{tabular}{crrrrr}
\hline months & Public Prices & Exchange Rate & Wages & Prices & Base Money \\
\hline $\mathbf{6}$ & 56.33 & 20.58 & 10.52 & 11.48 & 0.84 \\
$\mathbf{1 2}$ & 37.54 & 33.01 & 14.15 & 12.67 & 2.47 \\
$\mathbf{1 8}$ & 25.89 & 42.94 & 14.07 & 11.15 & 5.57 \\
$\mathbf{2 4}$ & 19.32 & 49.37 & 13.54 & 9.49 & 7.52 \\
$\mathbf{3 0}$ & 15.34 & 53.39 & 12.97 & 8.23 & 8.96 \\
\hline
\end{tabular}

As it is clear from the variance decomposition, in the medium and long run movements in base money and prices have been determined mainly by exogenous changes in exchange rates, wages, public sector prices, and the general price level. But the impact of exogenous movements in base money on prices, exchange rates and wages have been negligible. In addition, almost $90 \%$ of the variance in the monetary base is explained by shocks to the other variables of the system. This result highlights that to a very important degree monetary policy has accommodated these inflationary shocks. Exogenous shocks to money have been negligible, and they are almost irrelevant to explain the behavior of prices, exchange rates and wages. 
An alternative way of assessing the relevance of money supply shocks in explaining the behavior of inflation, is by estimating an equation for non-controlled prices 5 inflation as a function of exchange rate changes, wage changes and the rate of growth of base money. We also ran another equation that includes the growth rate of public sector prices as an additional explanatory variable. In both of these equations, the growth rate of the monetary base is statistically insignificant, when the movements in the other variables are taken into account, confirming that, in the period considered, exogenous shocks to money have not been the driving force behind the inflationary process in Mexico.

Table 6

Estimation of the monthly inflation of Non-Administrated prices

\begin{tabular}{lcc}
\hline Dependent Variable: & \multicolumn{2}{c}{$1987-1998$} \\
Non-Administrated Prices & 0.0276 & 0.0375 \\
\hline $\mathbf{C}$ & $(3.09)$ & $(4.60)$ \\
& 0.1286 & -- \\
Administrated Prices & $(1.77)$ & --- \\
& 0.0527 & 0.0689 \\
Exchange Rate & $(3.80)$ & $(5.64)$ \\
& 0.0812 & 0.1102 \\
Wages & $(2.81)$ & $(3.98)$ \\
& -0.0013 & -0.0016 \\
M1 & $(-0.12)$ & $(-0.12)$ \\
& 0.7209 & 0.8068 \\
Non-Administrated Prices (t-1) & $(12.57)$ & $(22.67)$ \\
& & \\
$\mathbf{R}^{2}$ & 0.9463 & 0.9272 \\
$\mathbf{R}^{2}$ adjusted & 0.9396 & 0.9186 \\
S.E. & 0.0055 & 0.0064 \\
\hline
\end{tabular}

5 By non-controlled prices we mean the subset of prices that are considered in the Mexican CPI that are market determined, i.e. there are not set by administrative rules established by the government, as is the case of prices of public sector goods. 
These results confirm that exogenous movements to the monetary base have not been a cause of inflationary pressures, but that the money base has accommodated inflationary shocks coming from the exchange rate, wages and public sector prices. These results ratify the conclusion offered above, in the sense that discretionary policy measures (or reactions) to combat shocks should
be the main component of México's monetary program.

In addition, the impulse response functions show that wages react significantly to shocks in the exchange rate and public sector prices, which suggests that these shocks significantly affected inflationary expectations (they were not interpreted as a once and for all adjustment in the CPI) which in turn affected wage demands. This indirect transmission channel by which exchange rate and public prices shocks affect inflation expectations and wage adjustments, is explicitly tested below.

So it is safe to assume that inflationary pressures in México have their origin in non-monetary factors (that have been validated ex-post by the monetary authority), among which we find: (a) the presence of external shocks which may generate sharp exchange rate depreciations; (b) changes in public sector prices; and (c) wage revisions that are inconsistent with the inflation target.

Confronted with these exogenous inflationary shocks, the central bank faces the decision to accommodate, totally or partially, the inflationary impact of such shocks, through its monetary policy actions, or not to accommodate at all. In order to understand the problems faced by the central bank, it is convenient to analyze first the case where there is some accommodation to these shocks.

Lets consider the case where an exogenous shock causes a sharp depreciation of the nominal exchange rate. If this depreciation is perceived as permanent, very rapidly it will translate into increases in tradable goods prices, generating a higher CPI. This would, in turn, increase nominal demand for money. If Banco de México matches passively demand and supply of base money, this expansion would be validated and the central bank would have accommodated the increase in money demand brought about by the exogenous shock to prices caused by the exchange rate depreciation.

In an economic textbook this would be described as a once and for all adjustment in the price level, and according to the textbook explanation, it should be accommodated and it will not cause further problems to the monetary authority.

However, and given our history of high inflation and the high historical correlation between exchange rate depreciations and inflation (see figure 10), the dynamics triggered by the exchange rate depreciation are complicated if one considers that the public might revise their inflationary expectations upwards, as it has been the case lately (see figure 11), which would lead to rises in wages and non- 
tradable goods prices, and, therefore, subsequent rounds of exchange rate and wage adjustments, thus, perpetuating inflation and monetary base growth. In figure 12 it is clear that the inflation in tradable goods has led the inflation of non-tradable goods since 1995, lending support to the hypothesis that exchange rate depreciations have both a direct and indirect impact on prices.

Other phenomena that would trigger inflationary pressures, similar to those described above, are the adjustments to public sector goods prices and wage increases that are not compatible with the inflation target. 
Figure 10

Inflation and Exchange Rate

(1984-1999)

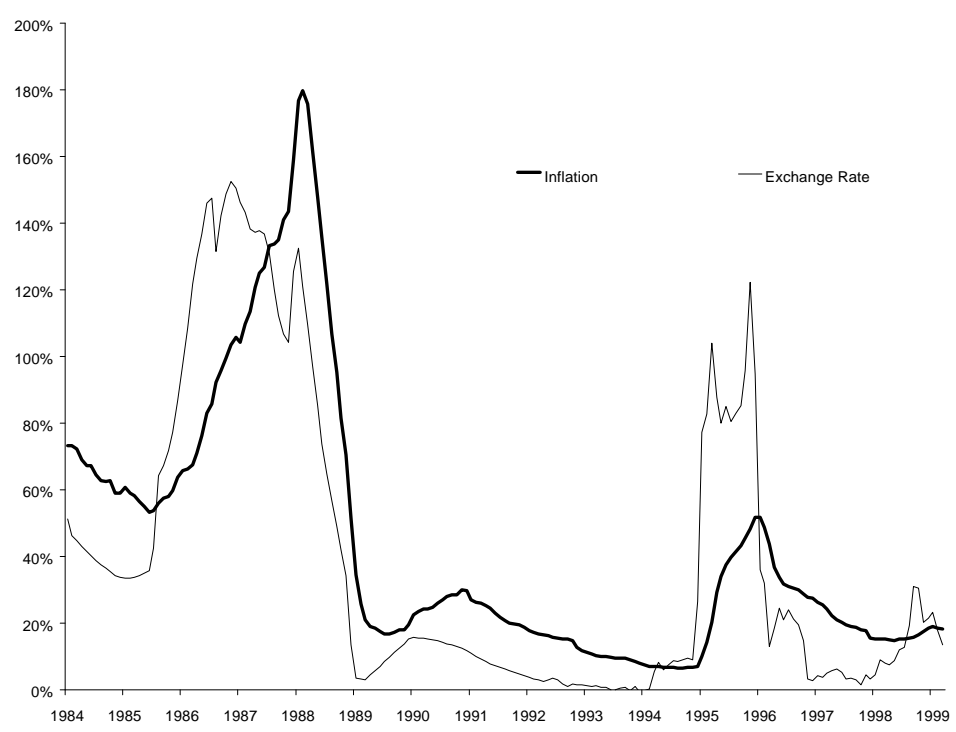

Figure 11

Relationship between inflation expectations and the exchange rate

(1997-1999)

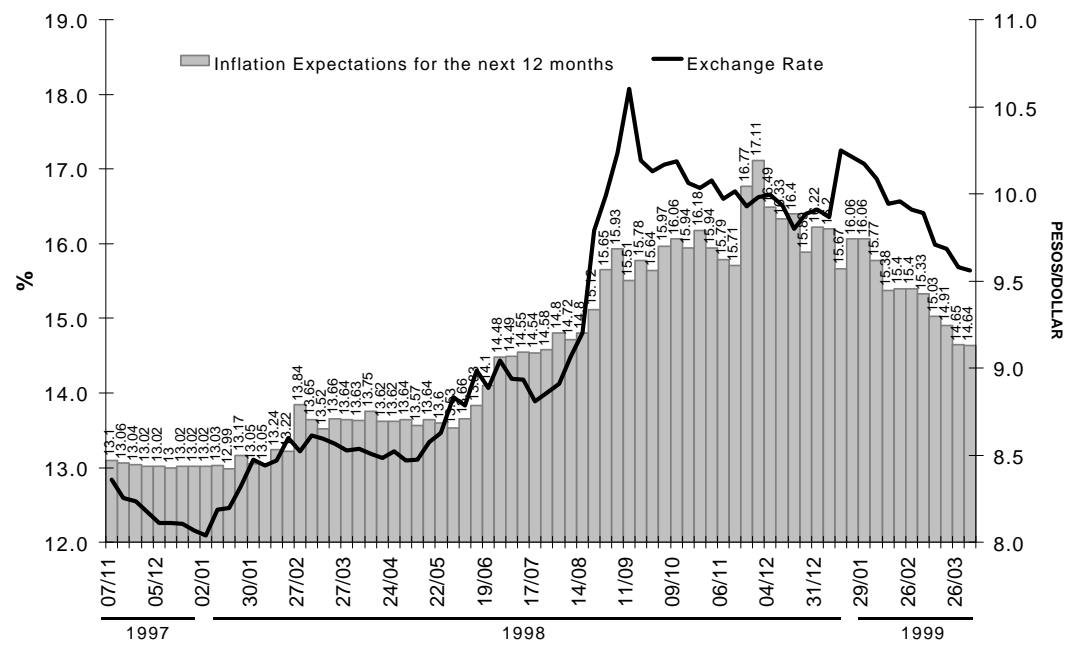

Source: INFOSEL and Banco de México.

Last figure: April 9, 1999.

To estimate the significance of the indirect channel of influence of the exogenous shocks, by which these affect expectations, and expectations affect wages, we estimated two equations, one to explain the behavior of inflation expectations and the other wage settlements. The first equation explains the change in inflation expectations for the next 12 months, taken from the weekly survey conducted by a Mexican wire system $\left(\pi_{t}^{e}\right)$. As explanatory variables we have the weekly depreciation of the exchange rate $\left(\Delta e_{t}\right.$ and $\left.\Delta e_{t-1}\right)$, inflationary surprises measured by the difference between 
observed and expected biweekly inflation ( $\Pi$ surt), the change in the "short" ( $\left.\Delta O B J_{t}\right)$ and increases in public sector prices $\left(\Delta \mathrm{PSP}_{\mathrm{t}}\right)$.

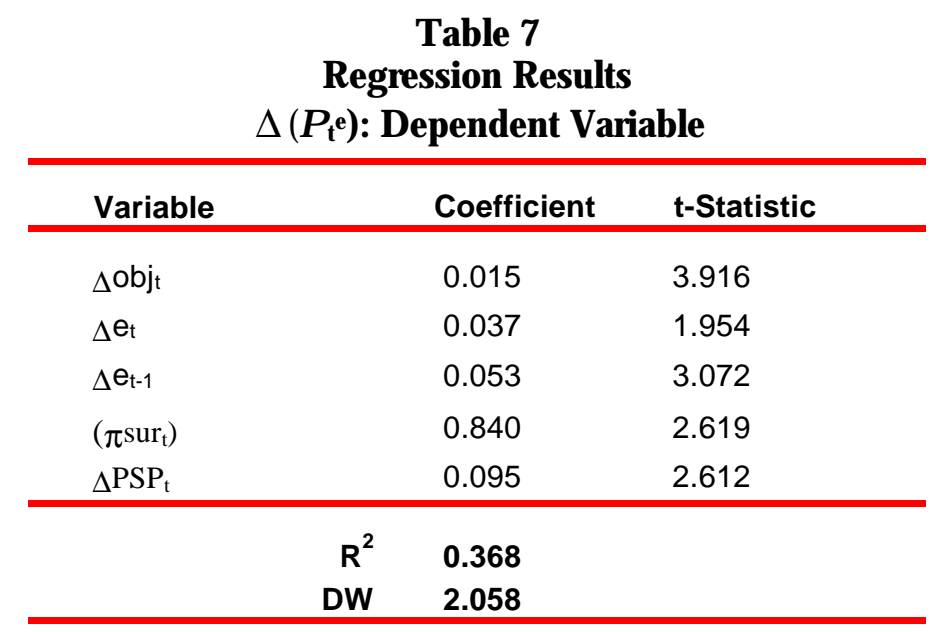

From the previous result, it can be derived that a 1 percentage point surprise in biweekly inflation affects inflation expectations for the next 12 months by 0.85 percentage point. This result shows that agents expect inflationary shocks to have an important permanent component. A $1 \%$ weekly depreciation affects inflation expectations by $0.08 \%$, while in those weeks when public sector prices have adjusted by $1 \%$, inflation expectations increased by $0.09 \%$. These results might be reflecting the fact that in the past Banco de México has accommodated, at least partially, some of the inflationary shocks, contributing to make them permanent. This is probably the main reason why the pass-through of exchange rate variations to inflation is relatively high in México. Not surprisingly, during the last two years at least, the Bank of México has been trying to brake this link, by modifying the "short" in response to sharp fluctuations in the exchange rate, minimizing the effects of changes in the prices of tradable goods and on the corresponding to non-tradables. 
Figure 12

TRADABLE AND NON TRADABLE GOODS INFLATION

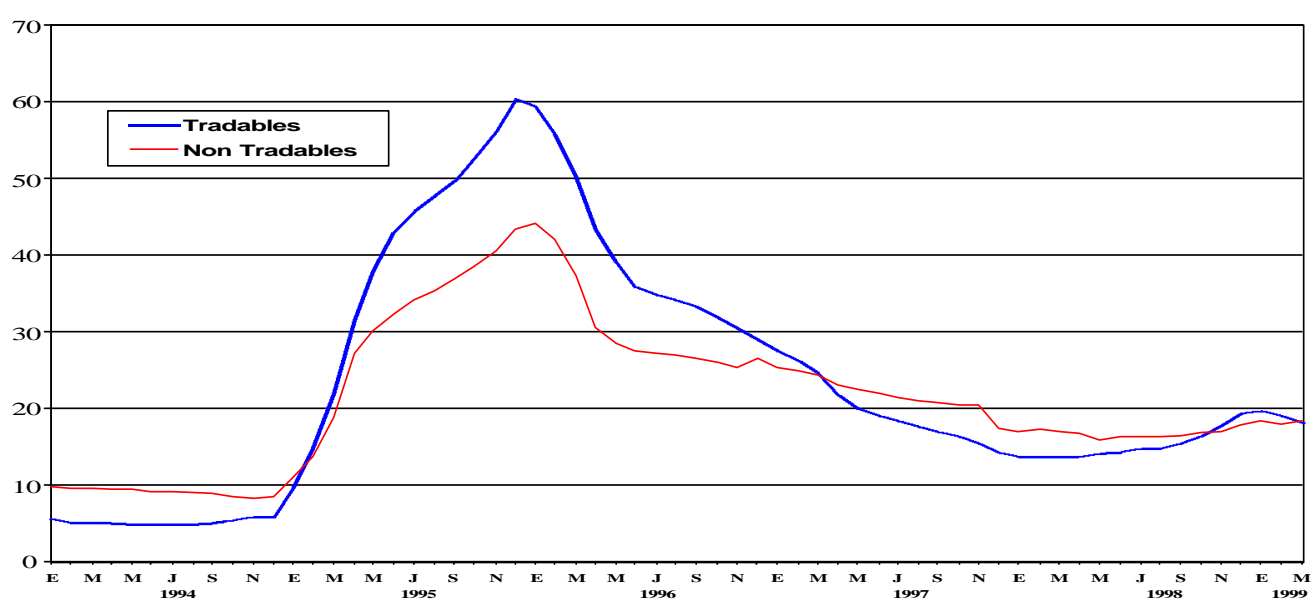

The second equation explains the behavior of wage inflation, measured by wage settlements, as a function of the previous month 12-month inflation $(\Pi \mathrm{t}-1)$, inflation expectations for the next 12 months $\left(\pi_{t}^{E}\right)$ and the growth rate of output $\left(\Delta \mathrm{Y}_{\mathrm{t}}\right)$.

Table 8

Regression Results

$\mathrm{WT}_{\mathrm{t}}$ : Dependent Variable

\begin{tabular}{ccccc}
\hline & \multicolumn{2}{c}{ Estimation 1 } & \multicolumn{2}{c}{ Estimation 2 } \\
Variable & Coefficient & t-Statistic & Coefficient & t-Statistic \\
\hline$\Pi_{\mathrm{t}-1}$ & 0.090 & 1.182 & 0.749 & 4.253 \\
$\Pi^{\mathrm{t}}$ & 0.197 & 2.012 & 0.318 & 1.557 \\
$\Delta \mathrm{Y}_{\mathrm{t}-3}$ & 0.114 & 2.179 & 0.107 & 2.283 \\
$\mathrm{WT}_{\mathrm{t}-1}$ & 0.707 & 6.402 & & \\
$\mathrm{AR}(1)$ & & & 0.672 & 5.481 \\
\hline $\mathbf{R}^{2}$ & 0.489 & & 0.326 & \\
DW & 2.114 & & 1.427 & \\
\hline
\end{tabular}

The results from these regressions clearly show that both lagged and expected inflation have an influence on wage settlements. Taken together, the equations reported in tables 7 and 8 confirm that transitory inflationary shocks --exchange rate movements and adjustment in public sector prices-- affect inflationary expectations and the correction in expectations influence wage behavior, confirming the importance of the indirect effects mentioned before and that also appeared in the impulse response 
functions from the VECM. These elements have generated significant inertial effects from inflationary shocks in México.

The central bank should be able to offset, at least partially, the inflationary impact of the exogenous disruptions on the exchange rate, public prices and contractual wages. This goal may be achieved if the central bank satisfies the daily monetary base demand, but at a rate above the one prevailing in the market. This is in fact what happens when Banco de México has applied or increased the "short". The resulting higher interest rates may, for example, partially reverse the impact of an exogenous exchange rate shock, limiting the exchange rate depreciation and moderating the adjustment of inflationary expectations. In fact, this was Banco de México's attitude during 1998, and it also has been in the elapsed time of 1999, as it sequentially increased the "short" as additional inflationary shocks became apparent (see figures 13 and 14). 


\section{Figure 13}

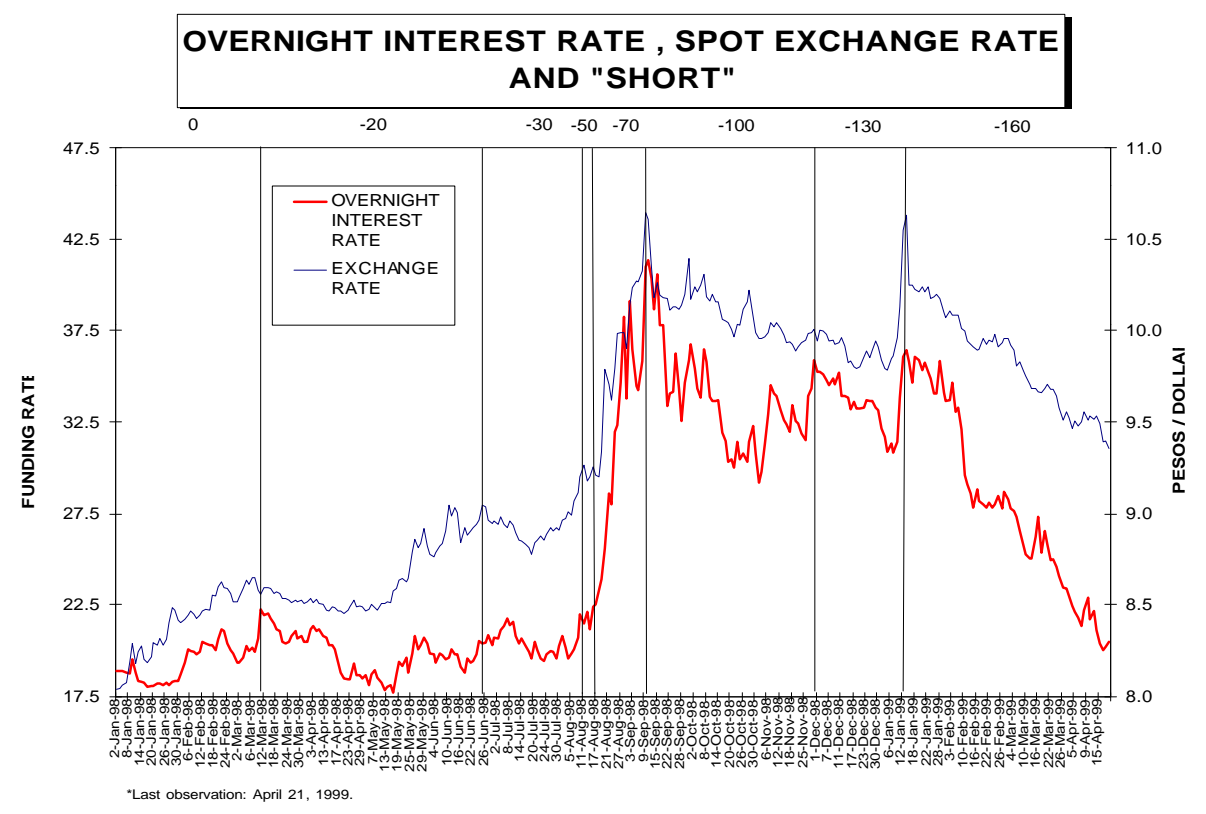

Figure 14

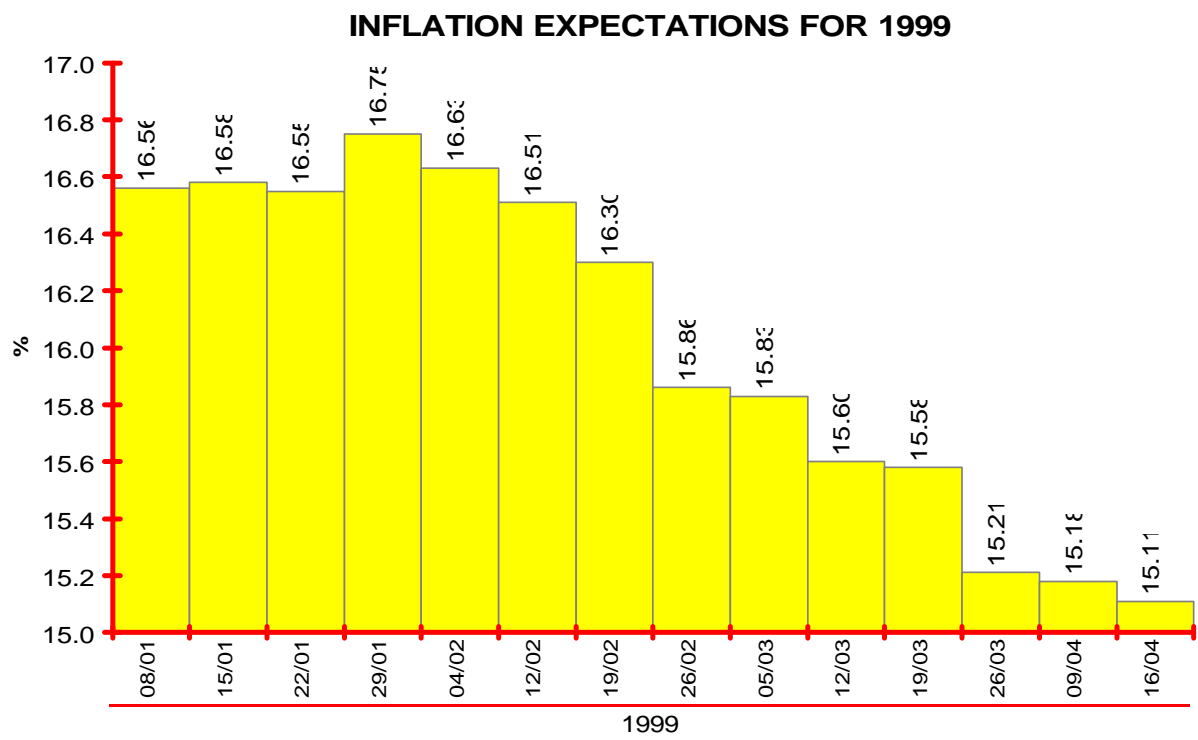

Source: INFOSEL and Banco de México. Last figure: April 16, 1999.

In the medium term, the rise in interest rates resulting from the authorities response to greater inflationary pressures will reduce monetary base growth. Such effect might be reinforced by the impact on demand for money of temporarily lower economic growth, associated to the rise in the cost of 
loanable funds. Additionally, of course, demand for monetary base would moderate in response to the achieved reduction in inflation.

Based on the above, it can be said that the dilemma that Banco de Mexico faces, when conducting monetary policy, consists in determining the degree to which the institution is able to counteract the inflationary shocks that eventually show up.

To the extent that monetary policy is extremely restrictive, entrepreneurs will find it more difficult to pass on to final prices the higher costs resulting from shocks like exchange rate depreciation, rises in public prices, or wage increases above expected inflation plus productivity gains. Profit margins would decrease, to become even negative, along with the possibility of domestic producers losing international competitiveness. All these elements might lead to lower investment and employment. Workers losing their jobs and the unemployed not finding one, would suffer the most from this situation. Therefore a very restrictive monetary policy can have a recessionary impact on economic activity, employment and investment. At the same time, such a policy stance could have undesirable effects on the health of the banking system. These two set of problems could even make the gains in the reduction in inflation unsustainable. This type of considerations have induced the Board of Governors of Banco de México to lean in favor of a gradual but sustainable path of desinflation.

The costs of the disinflationary process will be less, to the extent that the central bank enjoys more credibility among the public with respect to its conviction of abating inflation. Then, no substantial increases in interest rates would be required to keep inflationary expectations under control. But the central bank may only gain credibility by acting in a timely and consistent fashion when confronted with mounting inflationary pressures (which would show its commitment to the desinflation process). Therefore, to the extent that Banco de México is able to foster a more accelerated abatement of inflation, it will minimize the short-term costs of implementing a restrictive monetary policy. In fact, empirical evidence suggests that the lasting benefits of a lower inflation in the medium and long term will substantially compensate the temporary costs present in the process of converging towards price stability (see Ghosh and Phillips (1998)).

From the previous analysis, the basis on which Banco de Mexico can support a medium-term strategy to achieve a sustained reduction in inflation, can be derived. Namely:

a) Reaching social consensus regarding the benefits of price stability is imperative, in order to make inflationary expectations, as well as price adjustments, consistent with inflation targets. Thus, disinflation would be achieved at the least possible cost. 
b) Monetary policy, in addition to avoiding the primary cause of inflation - the generation of money supply surpluses -, should neutralize the secondary effects of the exogenous shocks on prices and should act in a precautionary fashion, in order to partially offset the direct inflationary effects of the key prices in the economy. The ultimate goal is reaching a situation where necessary adjustments in relative prices have a once and for all impact on the CPI - raising its level - but without deteriorating inflationary expectations, thus avoiding inflation dynamics from turning perverse. Eventually, the purpose is that by virtue of timely actions in monetary policy, Banco de México succeeds in making entrepreneurs, workers and investors, when making decisions, anticipate the possible reaction of the authority with regard to CPI disnuptions and minimize the repercussions on expectations. If such behavior is followed, the impact of these disnuptions on the economy will soften and credibility from the public with regard to Banco de México's inflation target will increase. This is how the disinflationary target should become eventually the nominal anchor of the Mexican economy.

c) Banco de Mexico should expand the horizon of its disinflationary commitments. By enlarging the time span, given the lags with which monetary policy actions affect prices, the central bank would be able to adjust, in a timely fashion, its stance on monetary policy without confusing the public. The monetary policy scheme would then make the central bank's actions easier to understand which would, in turn, act as an aid in anchoring the medium-term inflationary expectations.

d) The size and recurrence of pressures affecting inflation must be minimized as much as possible. Particularly, there must be a strategy to coordinate wage, fiscal and monetary policy. Such coordination is fundamental in achieving a sustainable abatement of inflation.

All these elements, in some way or another, are present in the 1999 monetary program of Banco de México.

\section{III.2. Exchange Rate Policy}

The exchange rate in México has been floating freely since late 1994. Nevertheless, at different stages since then, there has appeared for different reasons the need for the authorities to participate in the forex market. In all of these cases, the rule that always has been followed is that the intervention of the authorities in the forex market should be completely transparent, and without defending a particular level of the exchange rate - thus preserving the main characteristics of a flexible exchange rate regime.

As has been mentioned before, one of the most important elements of the crisis was the run on the country's external liabilities. On the public sector side, the run concentrated on the now famous TESOBONOS, that were dollar denominated government securities. Regarding the private sector, 
commercial banks faced difficulties in rolling-over their external liabilities. Even after the international assistance package was approved and the resources were available, and the adjustment program was already in place, relatively large amortizations of TESOBONOS and bank credits continued. Very soon it became obvious that if the excess demand for foreign exchange that generated this abrupt stock adjustment in the holdings of Mexican liabilities was not satisfied by official intervention, the depreciation of the floating exchange rate could have been enormous, with a risk of falling in a hyperinflation.

As a matter of fact, if the depreciation of the exchange rate had been the sole adjusting variable, such a price would have reached levels where less of a supply of forex would have resulted from additional depreciations (a back-bending supply curve would have ensued). Therefore, it was imperative to use the resources of the financial package to isolate the forex market from the token stock adjustment, and the indeterminacies that such an adjustment by itself would have created.

In line with the above, the authorities decided to open a special window at the central bank to cater the capital outflows related to the amortizations of TESOBONOS an commercial banks' credit lines. D ollar financing under this program was extended to 17 commercial banks. At its peak in early April, 1995, the outstanding credit granted through this facility reached only 3.9 billion dollars. By September, 1995, all participating banks had paid their outstanding debt in full.

As a matter of fact, by May of 1995 the floating exchange rate system began to work "normally". But, in any case, in the face of an abrupt stock adjustment, as the one México confronted in early 1995, the stabilization effort could not have worked without the assistance of the IMF and U.S. government loans, that allowed the "isolation" of the forex market from such a stock adjustment.

Another important element that has contributed to isolate the forex market from significant shocks, is that Banco de Mexico has been acting as the counterpart of the government, doing all of the resulting transactions at the daily "fix" exchange rate. In this way, the international reserves perform as an absorber to foreign exchange shocks (coming mostly from oil price fluctuations and external interest rate variations) affecting the government. In addition, given that the government typically runs a surplus in foreign currency, this practice has been helpful to increase our international reserves without intervening directly in the market.

In addition, in the aftermath of the crisis, México faced the need to reestablish its international reserves to a suitable level, for the reasons that have already been explained. In July of 1996, given the stability that the exchange rate exhibited during the first part of the year and that capital was flowing back to México, the Exchange Commission, integrated by officials from the Ministry of Finance and 
Banco de México and which is responsible for determining México's exchange rate policy, considered that foreign reserves at the central bank could be increased without causing disruptions in the foreign exchange market. Although the Commission considered it appropriate to accumulate a larger amount of international reserves, it also emphasized that this accumulation had to be done without affecting the behavior of the floating exchange rate and without sending any type of signals to the market that could be interpreted as desired levels for the exchange rate. In addition, it was important that the way in which the accumulation of reserves took place would encourage purchases of dollar when there was an excess supply of foreign currency, and discourage those purchases when there was an excess demand.

The scheme that was adopted to reach these objectives, still in operation, works as follows:

1) On the last business day of each month, Banco de México auctions rights to sell dollars to the central bank (put options) among credit institutions. These rights can be partially or completely exercised within the month following the respective auction.

2) Holders of these rights can sell dollars to Banco de México at the interbank exchange rate published for the previous business day, if the exchange rate is not higher than the average exchange rate for the 20 business days previous to the date on which these rights are exercised.

3) The expansion of the monetary base caused by Banco de México is completely sterilized. Therefore, the evolution of the supply of primary money is in no way affected by the aforementioned operations.

The mechanism just described went into operation in August 1996. In that month, the total amount of put options that was auctioned was exercised. Therefore, the central bank purchased 130 million dollars from commercial banks. In light of the acceptance of this mechanism among banks, and the favorable results of the first placement of options, in late August the Exchange Commission decided to increase the amount of rights to be auctioned per month to 200 million dollars, and to 300 million in December. On February 1996, the Exchange Commission decided that, starting that month, in the case that before the 16 of each month, $80 \%$ or more of the month's options had been exercised, a new auction of options would immediately take place, therefore doubling the potential monthly accumulation of reserves. On July 1997, the auction was increased to 500 million and in O ctober it was reduced to 400 million and to 250 in November. During 1998, this mechanism was suspended from October to December due to the extreme turbulence experienced in the forex market. This mechanism has accomplished its primary goal of accumulating international reserves without interfering with the functioning of the free float, and avoiding any misinterpretation of the intervention of the monetary authority in the foreign exchange market. 
Table 9

Results of the Auction of Options

\begin{tabular}{|c|c|c|c|}
\hline $\begin{array}{c}\text { Date } \\
\text { of the } \\
\text { Auction }\end{array}$ & $\begin{array}{c}\text { Amount } \\
\text { Auctioned } \\
\text { millions of us } \$\end{array}$ & $\begin{array}{l}\text { A umount } \\
\text { Excercised } \\
\text { millions of us\$ }\end{array}$ & $\begin{array}{l}\text { Percentage } \\
\text { Excercised }\end{array}$ \\
\hline Aug-7-96 & 130 & 130 & $100.0 \%$ \\
\hline Aug-30-96 & 200 & 200 & $100.0 \%$ \\
\hline Sep-30-96 & 200 & 179 & $89.5 \%$ \\
\hline Oct-31-96 & 200 & 200 & $100.0 \%$ \\
\hline Nov-29-96 & 200 & 200 & $100.0 \%$ \\
\hline Dec-30-96 & 300 & 300 & $100.0 \%$ \\
\hline Jan-31-97 & 300 & 300 & $100.0 \%$ \\
\hline Feb-21-97 & 300 & 148 & $49.3 \%$ \\
\hline Feb-28-97 & 300 & 120 & $40.0 \%$ \\
\hline Mar-31-97 & 300 & 300 & $100.0 \%$ \\
\hline Apr-15-97 & 300 & 263 & $87.7 \%$ \\
\hline Apr-30-97 & 300 & 300 & $100.0 \%$ \\
\hline May-30-97 & 300 & 20 & $6.7 \%$ \\
\hline Jun-30-97 & 300 & 300 & $100.0 \%$ \\
\hline Jul-9-97 & 300 & 300 & $100.0 \%$ \\
\hline Jul-31-97 & 500 & 500 & $100.0 \%$ \\
\hline Aug-29-97 & 500 & 500 & $100.0 \%$ \\
\hline Sep-30-97 & 400 & 375 & $93.8 \%$ \\
\hline Oct-31-98 & 250 & 250 & $100.0 \%$ \\
\hline Nov-28-97 & 250 & 250 & $100.0 \%$ \\
\hline Dec-15-97 & 250 & 250 & $100.0 \%$ \\
\hline Dec-30-97 & 250 & 49 & $19.6 \%$ \\
\hline Ene-30-98 & 250 & 0 & $0.0 \%$ \\
\hline Feb-27-98 & 250 & 250 & $100.0 \%$ \\
\hline Mar-31-98 & 250 & 250 & $100.0 \%$ \\
\hline Apr-7-98 & 250 & 210 & $84.0 \%$ \\
\hline Apr-30-98 & 250 & 149 & $59.6 \%$ \\
\hline Мау-29-98 & 250 & 0 & $0.0 \%$ \\
\hline Jun-30-98 & 250 & 250 & $100.0 \%$ \\
\hline Jul-14-98 & 250 & 250 & $100.0 \%$ \\
\hline Jul-31-98 & 250 & 0 & $0.0 \%$ \\
\hline Aug-31-98 & 250 & 20 & $8.0 \%$ \\
\hline \multicolumn{4}{|l|}{ Sep-30-98 } \\
\hline $0 c t-30-98$ & & NO AUCTION & \\
\hline \multicolumn{4}{|l|}{ Nov-30-98 } \\
\hline Dec-30-98 & 250 & 215 & $86.0 \%$ \\
\hline Jan-29-99 & 250 & 250 & $100.0 \%$ \\
\hline Feb-26-99 & 250 & 250 & $100.0 \%$ \\
\hline Mar-31-99 & 250 & 250 & $100.0 \%$ \\
\hline Total & 9.830 & 7,778 & $79.1 \%$ \\
\hline
\end{tabular}

Both, theory 6 and practice have shown that the accumulation of reserves through this mechanism is sufficiently neutral to changes in the volatility and trend driving the exchange rate process. Therefore its establishment did not send any type of signals regarding the preferences of the central bank towards exchange rate changes or its volatility.

In several occasions under the floating exchange rate regime, when the domestic currency experienced sharp depreciations, liquidity in the forex market almost dryed up. Under such circumstances, small changes in the demand for foreign currency led to disproportionate depreciations of the peso. These conditions might lead to devaluatory spirals that can seriously affect inflation and interest rates. In order to moderate these extreme situations, a contingent dollar sales scheme was introduced in February of 1997. According to this scheme, Banco de Mexico auctions everyday 200 million dollars with a minimum price that is two percent above the preceding day's exchange rate. This scheme is not intended to defend specific levels for the exchange rate, but only to moderate exchange rate volatility by reestablishing a minimum level of liquidity in stressful times.

\footnotetext{
${ }^{6}$ See Werner, A and Milo, A (1998) "Acumulación de Reservas Internacionales a través de la venta de opciones: el caso de México" Documento de Investigación No. 9801, Banco de México.
} 
Additionally, it should be pointed out that, by selling dollars through auctions and avoiding the defense of specific exchange rate levels, the exchange rate will rapidly reach the stage where foreign currency supply and demand reach equilibrium. Furthermore, it is possible that, by merely suggesting that the central bank might be willing to sell 200 million dollars, subject to the exchange rate depreciating two percent of further within the day, the likelihood of devaluatory spirals would be reduced.

As a result of the international market volatility generated by the Asian, Russian and Brazilian crises, this mechanism was activated in several occasions. Banco de México's contingent dollar sale mechanism fostered greater stability and order in the currency exchange market without having compromised an excessive amount of international reserves during these periods, proving to be a suitable mechanism to reduce the volatility in the foreign exchange market.

\section{Stylized Facts under México's Float}

First of all, we should mention that given the macroeconomic framework that has been maintained during the period of study, the floating exchange rate regime has not been an impediment to achieve a fast disinflation from a rate of $51.7 \%$ in 1995 to $18.6 \%$ in 1998 (with a temporary interruption during the second semester of 1998, due to the distress in the world economy). This disinflation coincided with a relatively high rate of growth of the Mexican economy. 
Figure 15

GDP and Inflation

(annual growth rates)

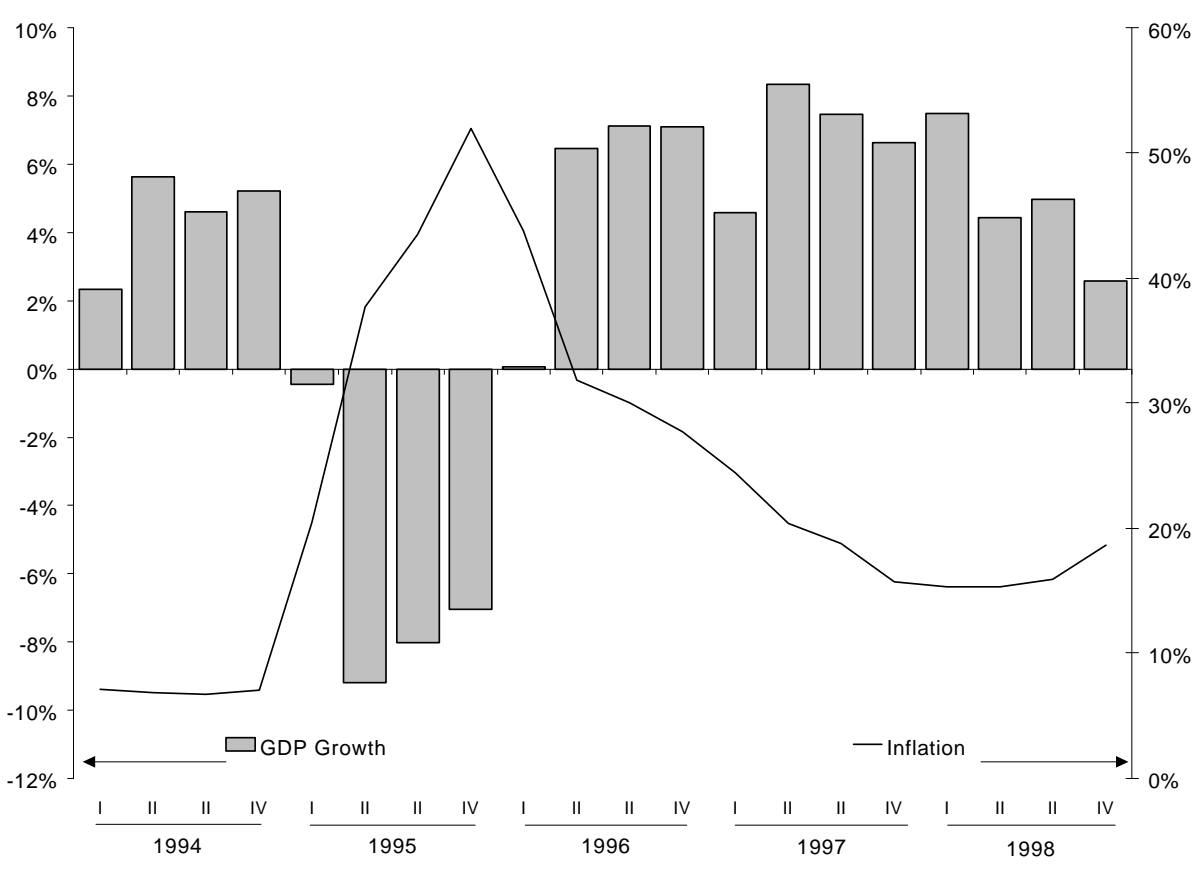

Immediately after the adoption of the floating exchange rate, the movements in the currency were erratic and significant depreciations took place. This behavior is entirely explained by the uncertainty regarding the policy measures that were going to be implemented in response to the crisis and the acute international liquidity problem that the country was facing. Since April 1995, after the announcement of the IMF program and the international assistance package, the currency stabilized and the foreign exchange market was relatively stable until October, when another episode of high volatility and large depreciations started. Again, the main reason behind this episode was the uncertainty regarding the macroeconomic program for 1996 and the health of the financial system. Once these issues were cleared, the foreign exchange market has experienced long periods of stability that have been temporarily interrupted by bouts of volatility. In addition, and as a result of the Russian default, the currency suffered another episode of large depreciations and volatility from September to November of 1998. As a matter of fact, the peso experienced then an overshooting, that has been in the process of correction since December, 1998 with a small interruption due to the brazilian real devaluation (see figure 16). 
Figure 16

Spot Exchange Rate

(1995 - 1999)

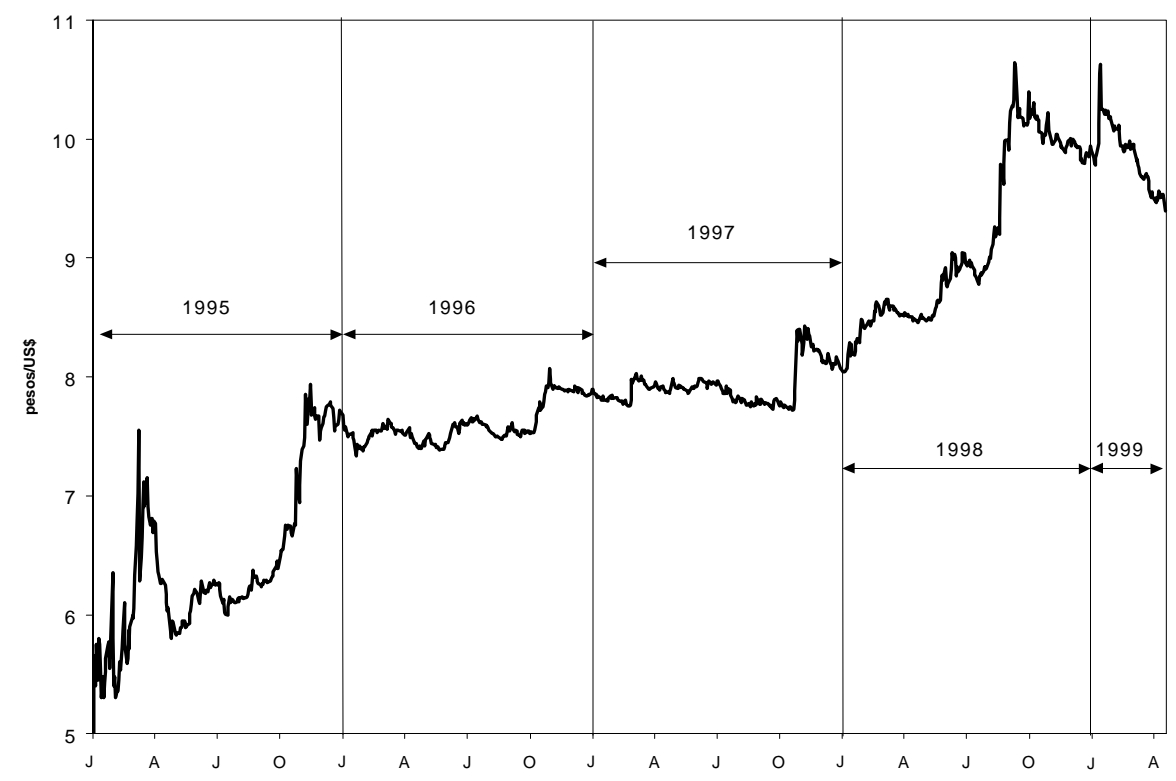

The existence of an efficient foreign currency futures market has been of great use in order to diminish the volatility of the exchange rate. According to the sales or purchases carried out in this market, both importers and exporters and, in general, creditors and debtors of foreign currency, are able to eliminate or substantially reduce the exchange rate risks they face and thus alleviate pressures on the spot market. Therefore, Banco de Mexico authorized banks complying with certain conditions, particularly those related to technical qualification and solvency, to carry out operations in foreign exchange futures. In 1995, Banco de México also issued the necessary provisions to facilitate the operation of a Mexican peso futures market at the Chicago Mercantile Exchange.

Overall, the volatility experienced by the Mexican peso during its float, once the macroeconomic and financial crises were contained, has been similar to that experienced by other currencies with a floating exchange rate regime. Since 1996, the implementation of consistent fiscal, monetary and exchange rate policies, the programs implemented to restructure the financial system and the accumulation of international reserves by Banco de Mexico, reestablished confidence on our macro framework and as a result we have seen usually an orderly behavior of the peso. 


\section{Table 10}

EXCHANGE RATE VOLATILITY OF SOME COUNTRIES VIS-A-VIS THE USD

\begin{tabular}{|c|c|c|c|c|c|c|c|c|c|}
\hline & \multicolumn{9}{|c|}{ Anualized Volatility* (Percent) } \\
\hline & 1995-I & 1995-II & 1996-I & 1996-II & 1997-I & 1997-II & |1998-I & 1998-II & $1999-I^{\star \star}$ \\
\hline Mexico & $48.56 \%$ & $17.60 \%$ & $5.99 \%$ & $5.31 \%$ & $4.92 \%$ & $10.69 \%$ & $6.68 \%$ & $10.95 \%$ & $10.75 \%$ \\
\hline New Zealand & $6.67 \%$ & $5.35 \%$ & $5.56 \%$ & $6.01 \%$ & $5.88 \%$ & $8.61 \%$ & $12.45 \%$ & $14.95 \%$ & $9.51 \%$ \\
\hline Australia & $8.86 \%$ & $7.87 \%$ & $6.10 \%$ & $6.70 \%$ & $7.65 \%$ & $10.29 \%$ & $11.91 \%$ & $14.93 \%$ & $12.58 \%$ \\
\hline Finland & $12.85 \%$ & $9.13 \%$ & $7.43 \%$ & $7.28 \%$ & $10.04 \%$ & $9.51 \%$ & $8.31 \%$ & $9.17 \%$ & $9.15 \%$ \\
\hline Suecia & $12.70 \%$ & $9.91 \%$ & $8.02 \%$ & $7.28 \%$ & $10.26 \%$ & $10.58 \%$ & $9.57 \%$ & $12.59 \%$ & $9.00 \%$ \\
\hline Canada & $5.13 \%$ & $5.92 \%$ & $3.64 \%$ & $3.33 \%$ & $5.46 \%$ & $4.24 \%$ & $4.32 \%$ & $6.95 \%$ & $5.67 \%$ \\
\hline Italy & $13.97 \%$ & $7.22 \%$ & $5.97 \%$ & $5.73 \%$ & $8.95 \%$ & $9.15 \%$ & $7.82 \%$ & $9.29 \%$ & $9.16 \%$ \\
\hline South Africa & $5.64 \%$ & $2.34 \%$ & $13.86 \%$ & $7.20 \%$ & $5.25 \%$ & $4.34 \%$ & $5.35 \%$ & $23.07 \%$ & $14.96 \%$ \\
\hline United Kingdom & $10.45 \%$ & $7.41 \%$ & $5.60 \%$ & $6.30 \%$ & $8.13 \%$ & $8.03 \%$ & $7.11 \%$ & $7.33 \%$ & $7.16 \%$ \\
\hline Switzerland & $16.67 \%$ & $12.13 \%$ & $7.77 \%$ & $8.84 \%$ & $11.70 \%$ & $9.81 \%$ & $8.70 \%$ & $10.91 \%$ & $10.15 \%$ \\
\hline Japan & $14.12 \%$ & $14.04 \%$ & $8.14 \%$ & $7.09 \%$ & $12.56 \%$ & $12.29 \%$ & $12.56 \%$ & $20.08 \%$ & $14.92 \%$ \\
\hline Germany & $13.87 \%$ & $10.89 \%$ & $6.28 \%$ & $6.87 \%$ & $9.79 \%$ & $9.76 \%$ & $8.14 \%$ & $9.15 \%$ & $9.17 \%$ \\
\hline
\end{tabular}

Although it has been argued that by floating the exchange rate a country has an additional adjustment variable to confront external shocks and therefore the volatility of interest rates should come down, this is not necessarily true. When adopting a flexible exchange rate, a country also abandons the use of its international reserves as an adjustment variable to absorb transitory external shocks. Thus, we should think that when moving from a fixed to a floating regime a country changes its adjustment variables from international reserves and interest rates to the nominal exchange rate and interest rates. So, it is not obvious that interest rate volatility should decline when a country adopts a floating exchange rate regime.

As a simple test of the effects of the different exchange rate regimes on interest rate levels and volatilities, we compare the behavior of interest rates in the 1996-1999 period with that observed during 1989-1994. These periods share similar inflation performances: during 1996-1998 inflation was 27.7, 15.7 and 18.6\% respectively, while in the 1989-1991 period the rate of inflation was 19.7, 29.9 and $18.8 \%$ respectively. On the other hand during the more recent period we had a floating exchange rate regime and in the 1988-94 period we had a predetermined exchange rate system. 
Figure 17

Funding Rate

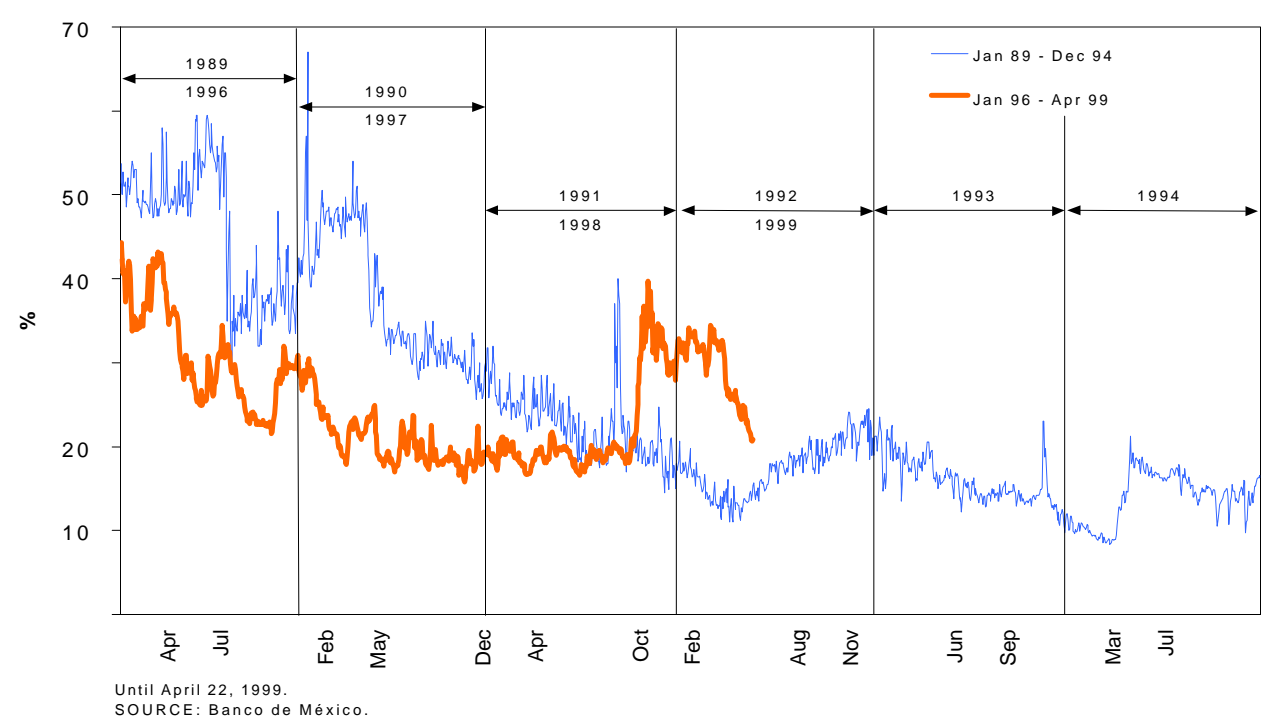

Figure 18

Funding Rate Volatility

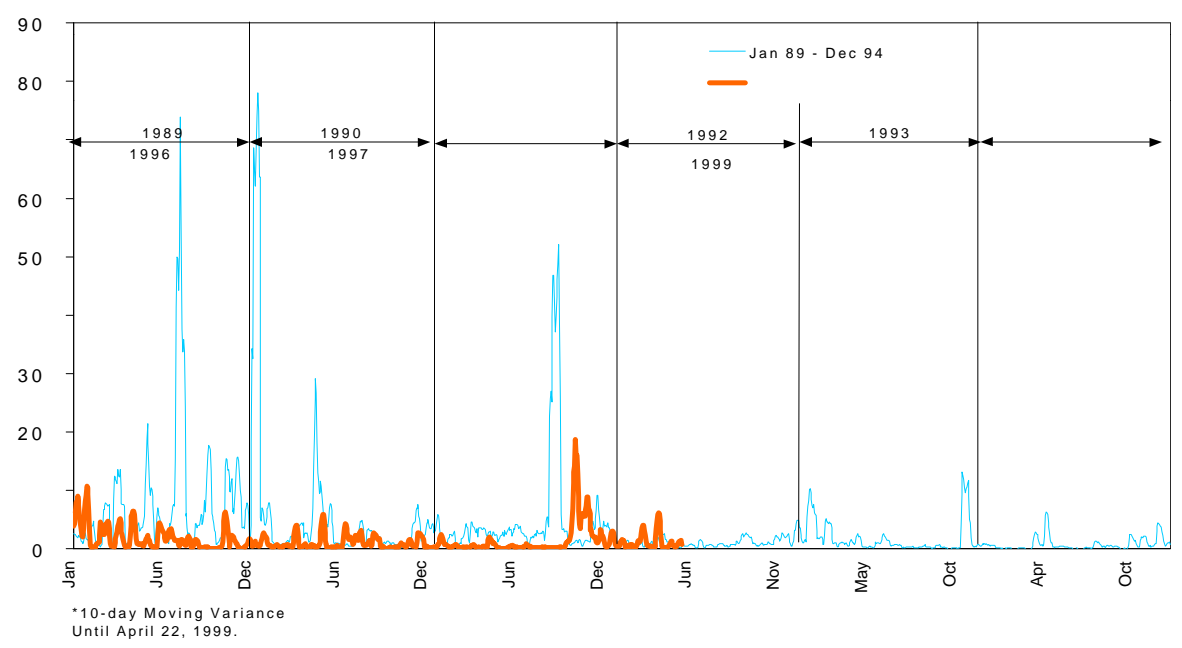

It is clear that in the current stabilization effort, under a floating exchange rate, interest rates have been usually lower and less volatile than what was observed during the years of the Pacto (1997 1994).

In México's experience, the adoption of a floating exchange rate regime has substantially contributed in reducing speculative pressures in financial markets. A very important feature of this regime is that it discourages short-tem capital flows, due to the large losses that can be incurred by 
investors in the short-run. As it is clear from figures 19 and 20, the recent Mexican experience highlights this phenomenon, as the ratio of FDI to the current account deficit has increased significantly since the adoption of this regime. The reaction of the FDI to current account ratio deficit in México has been larger than the one observed in other Latin-American countries that have not changed their exchange rate regime.

Figure 19

Current Account and Foreign Direct Investment (\% GDP)

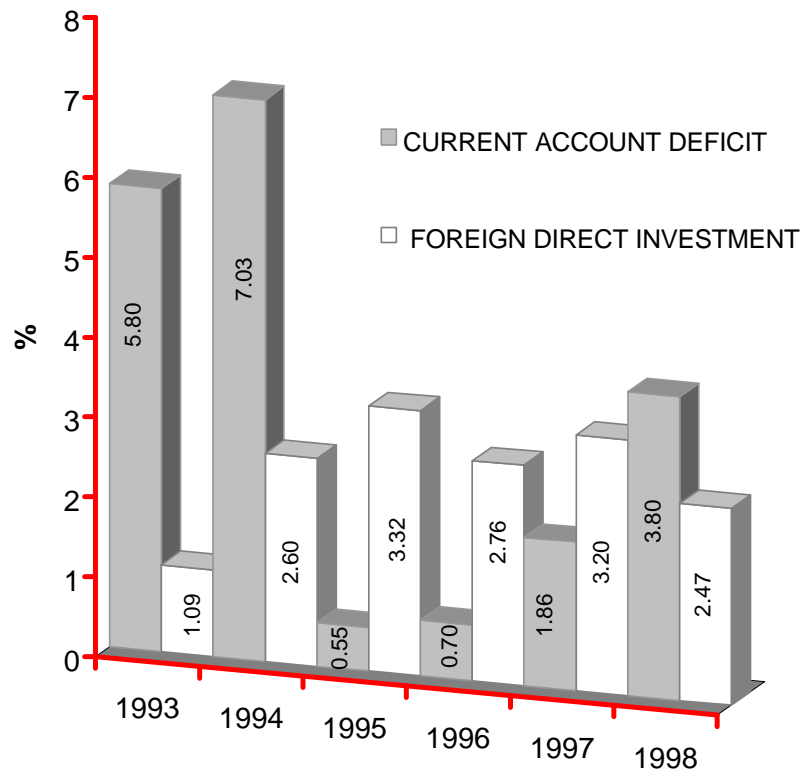

SOURCE: Banco de México. 


\section{Figure 20}

\section{Average Foreign Direct Investment for Mexico and Latin America}

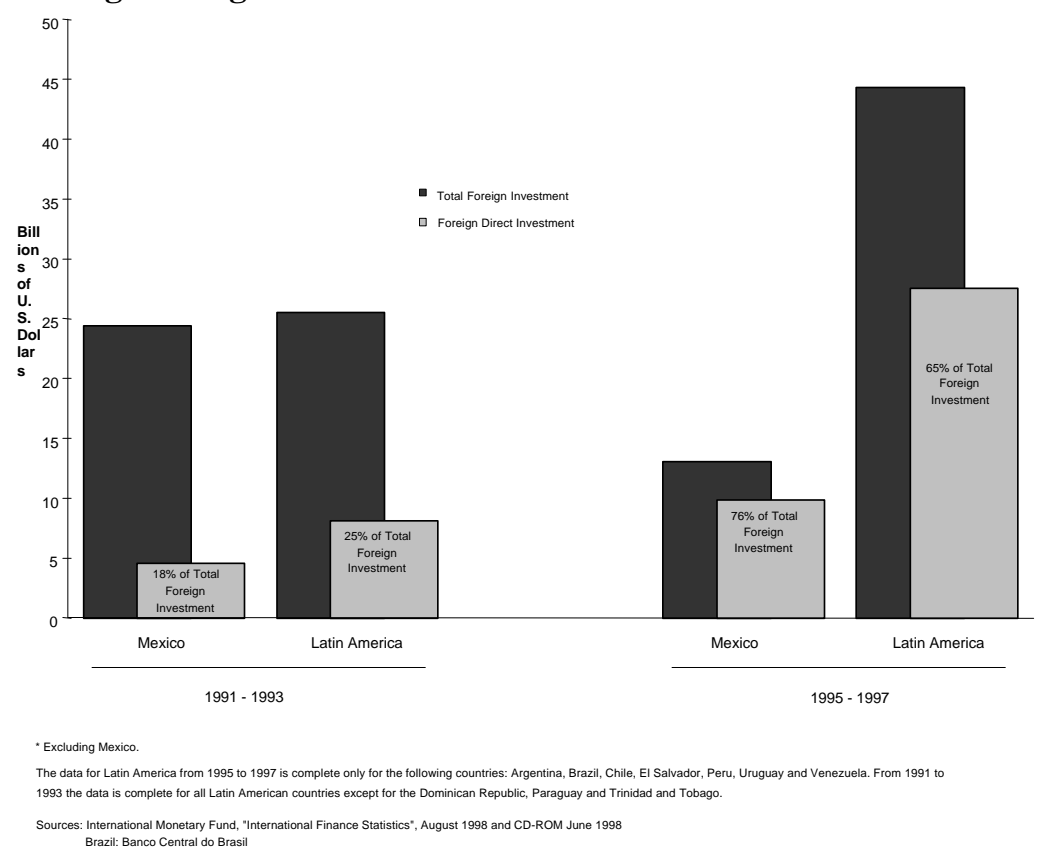

It is important to highlight the stabilizing properties of the floating exchange rate system and the free determination of interest rates when the economy faces a capital outflow (although not as large as the observed in México in early 1995). Under these circumstances, the downloading of assets denominated in domestic currency will bring about a depreciation of the currency and an increase in interest rates. The simultaneous movements in these variables depresses asset prices, and discourages further selling, stopping the capital outflow. The automatic movements in exchange rates and interest rates increases the price of speculating again the domestic currency. Given the fact that the levels that these variables reach during these episodes are inconsistent with the fundamentals of the economy, the currency will recover sooner or later, inflicting considerable losses to those who acquired the foreign currency at a high price and sold their domestic assets at rock bottom prices.

The flexible exchange rate also facilitates the adjustment of the real exchange rate towards its equilibrium level whenever an external shock warrants a new equilibrium real exchange rate, without seriously affecting the credibility of the monetary authority. The best example of this role for the exchange rate is what we witnessed last year with the currencies of Australia, Canada and New Zealand.

These small open economies were affected severely by the fall in their terms of trade and the fall in demand from the Asian crises countries. As a reaction to these shocks, the currencies of these countries depreciated by large amounts. These currency movements were useful in diminishing the real effects of the aforementioned shocks. A similar phenomenon happened in México, as our terms of 
trade fell by $5.5 \%$ and the international financial markets turned their backs on emerging markets. Both of these shocks should depreciate the equilibrium real exchange rate, justifying the observed depreciation of the currency.

Figure 21

Real Exchange Rate

(1998)

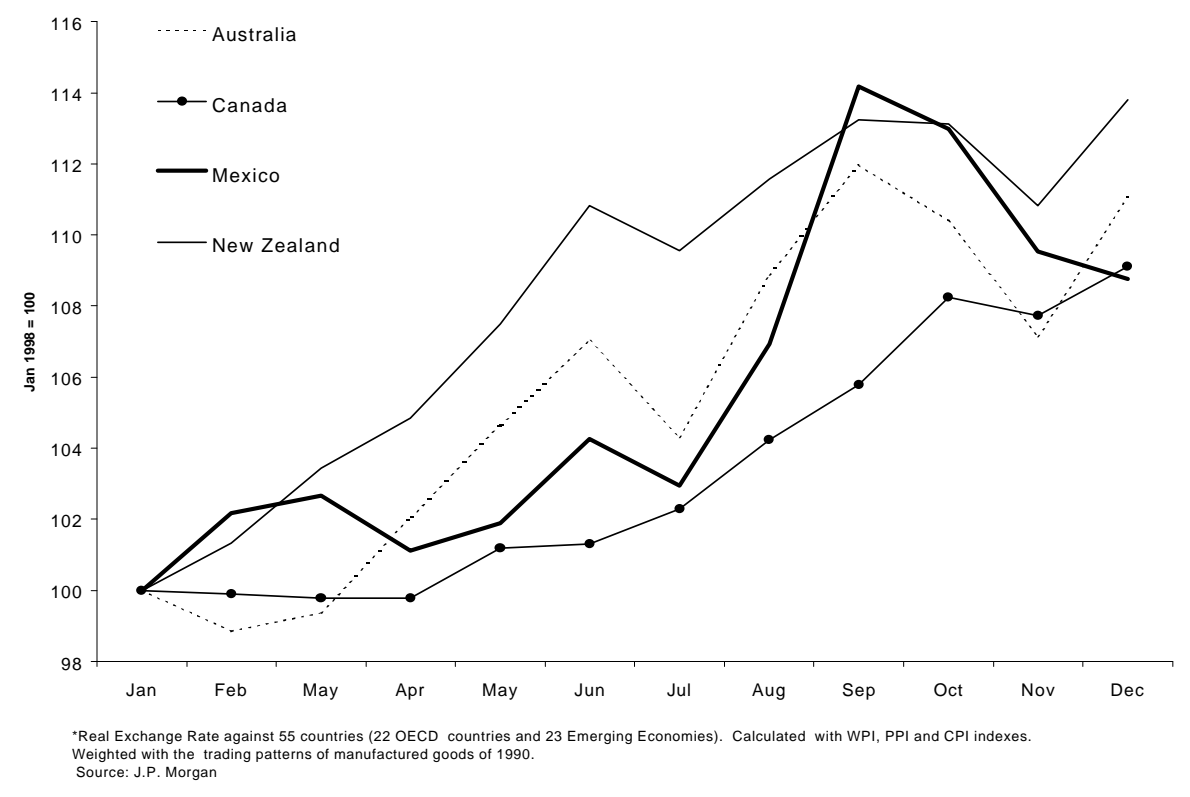

These movements in the real exchange rate were useful to minimize the effects of the aforementioned shocks on the economy. During 1998, Mexico's G DP grew by $4.8 \%$, only $0.2 \%$ below the growth rate expected at the beginning of the year, in part due to significant growth of non-oil exports (11.3\%). However, given our history of high inflation and the high historical correlation exhibited between depreciations and inflation, as the exchange rate depreciated inflation expectations immediately reacted. Therefore, the inflation cost of achieving the necessary correction in the real exchange rate was around 2.2 percentage points and the nominal depreciation needed to achieve the same movement in the real exchange rate had to be significantly larger that the ones in the other countries considered (See 1999 Monetary Program, Banco de Mexico). 


\section{Figure 22 \\ Nominal Exchange Rate (1998) \\ (Jan 1998=100)}

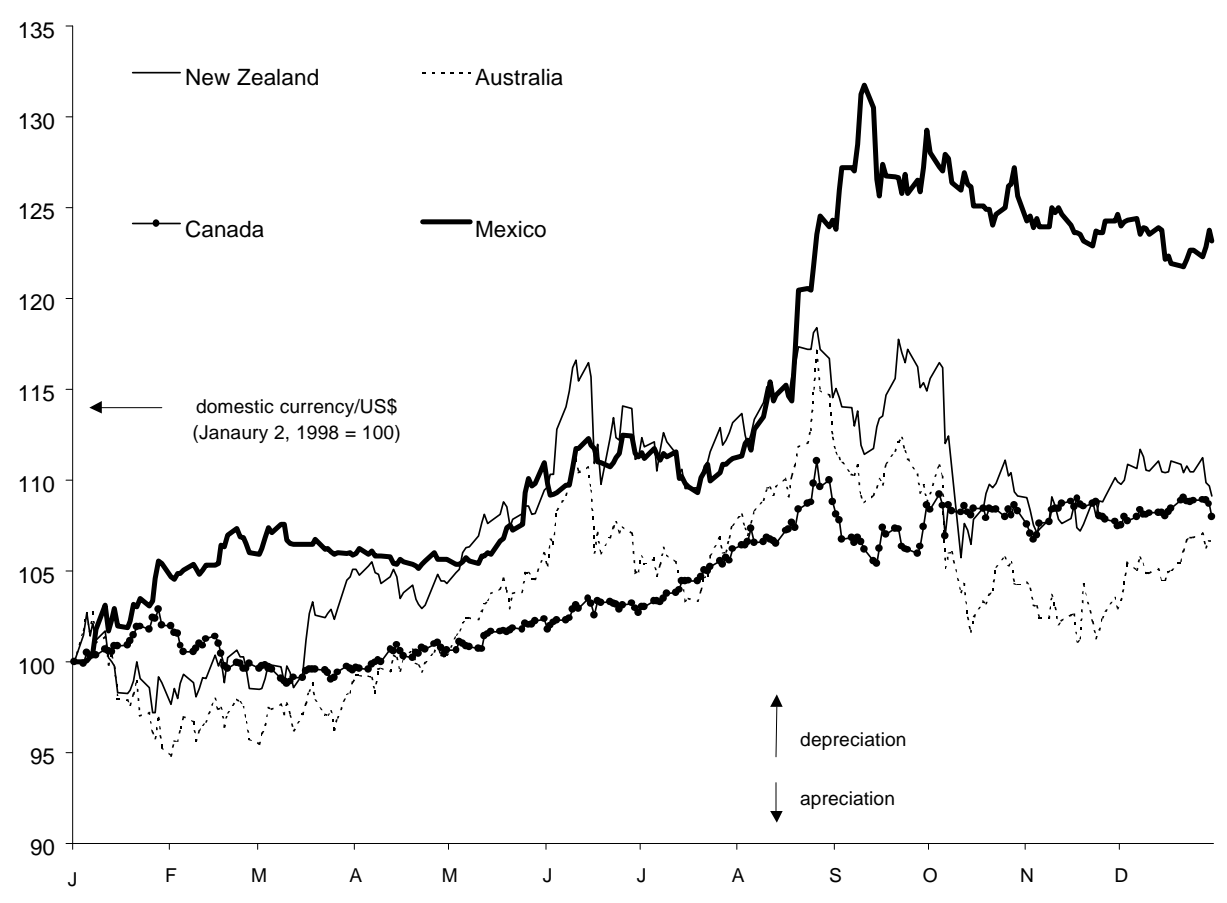

A brief comparison between the speed of the passthrough effects in México and Australia highlights the problem the former faces due to its previous inflationary history. Although the long term impact of an exchange rate depreciation on non controlled prices is similar in México and Australia (a 1\% depreciation translates into a 0.55\% inflation in Mexico and $0.44 \%$ inflation in Australia), in our country half of this effect takes place after 2 quarters, while $82 \%$ takes place within the year. On the other hand, in Australia7, only 7\% takes place after 2 quarters and 14\% after 4 quarters.

As we mentioned in the previous section, due to the high pass-through from exchange rate depreciation to inflation, during 1998 Banco de Mexico had to tighten monetary policy sequentially to counteract the effects on inflation.

To reduce the high speed at which peso depreciations feed into inflation, is one of the key challenges that monetary policy faces in the future, so as for México to be able to take full advantage of the floating exchange rate regime and let the exchange rate play its "relative price" role instead of being a signal for future inflation.

\footnotetext{
7 See Ericsson and de Brouwer (1998).
} 


\section{Final Remarks}

Recent emerging market crises have reignited the debate on the optimal exchange rate regime for emerging markets. In addition, there is a widespread agreement that the costs of policy mismanagement have increased significantly and in several occasions were not proportional to the policy slippages undertaken on the crises countries. Therefore, independently of the choice of exchange rate arrangements, the recent financial market crises underscores the importance of maintaining a consistent macroeconomic framework to avoid financial and balance of payments crises and achieve long-lasting stability.

In relation to the conduct of monetary policy, it is clear that assigning multiple objectives to this single policy instrument, has led to the collapse of several predetermined exchange rate regimes. Because of this, one of the most important steps undertaken after the collapse of the Mexican peso was to spell out clearly that monetary policy was going to be focused exclusively in attaining its medium run goal of price stability and that the banking sector problem was going to be addressed by specific programs, whose cost was going to be assumed by the fiscal authority. In this regard, the recent Mexican experience highlights the importance of following consistent macroeconomic policies to accomplish a long lasting stabilization.

The evolution of monetary policy since the adoption of the floating exchange rate regime has converged on a framework that includes three main elements: an annual inflation target, the establishment of rules with respect to the evolution of base money and the use of discretionary measures to affect interest rates in the pursuit of our inflation target. This mixture of rules and discretion has worked well in recent years. On the one hand, the establishment of rules and quantitative commitments described in the paper has been helpful in guaranteeing the public that Banco de México will not create the most basic source of inflation: excess supply of base money. Due to the high pass-through of inflationary shocks, the instability in the demand for base money and the difficulty in affecting monetary aggregates in the short run, the strict application of our rules, does not guarantee that the inflation target will be met. Therefore, to be in a position to quickly react to inflationary shocks, Banco de México has the possibility to discretionally adjust its monetary policy stance to influence the behavior of the interest rates in the pursuit of its inflation target. Therefore, as time has passed, the inflation objective, supported by our discretionary actions, has become the nominal anchor of the economy.

Going back to the discussion on exchange rate arrangements for emerging markets, our experience has shown that the Mexican peso has been as stable as other floating currencies, contrary to the original forecasts of several analysts. Therefore, this exchange rate regime has not represented an 
obstacle in our disinflationary efforts and it has contributed significantly to the adjustment of the economy to external shocks and to discourage short-term capital inflows. Thus, the floating exchange rate has become a very important element of México's current macroeconomic policy framework. 


\section{References}

Banco de México, (1999), “Política Monetaria, Progrma para 1999”

Banco de México, "The Mexican Economy”, Various Issues

Banco de México, (1998), "La Política Monetaria en la Coyuntura Actual y para el Desarrollo Económico de Largo Plazo: Retos y Posibilidades"

Ericsson, N. and G. de Brouwer, (1998), "Modeling Inflation in Australia", Journal of Business and Economic Statistics, Vol. 16, No. 4.

Ghosh, A. and S. Phillips, (1998) "Warning: Inflation May Be Harmful to Your Growth”, International Monetary Fund Staff Papers, Vol. 45, No. 4, D ecember.

Gil Díaz, F., (1998), "Monetary Policy and its Transmission Channels in Mexico" in "The Transmission of Monetary Policy in Emerging Market Economies", Bank for International Settlements, Monetary and Economic D epartment.

Hausmann, R., M. Gavin, C. Pages-Serra and E. Stein, (1999), "Financial Turmoil and the Choice of Exchange Rate Regime", mimeo, IADB.

Lucas, R., (1996), “Nobel Lecture: Monetary Neutrality”, Journal of Political Economy, Vol. 104.

Werner, A. and A. Milo (1998), "Acumulación de reservas internacionales a través de la venta de opciones: El caso de México”, Banco de México, Documento de Investigación No. 9801. 